This item was submitted to Loughborough's Research Repository by the author.

Items in Figshare are protected by copyright, with all rights reserved, unless otherwise indicated.

\title{
Unity in bronze: German universities and the 250th anniversary of the Royal Society
}

PLEASE CITE THE PUBLISHED VERSION

https://doi.org/10.1098/rsnr.2020.0051

PUBLISHER

The Royal Society

VERSION

AM (Accepted Manuscript)

\section{PUBLISHER STATEMENT}

This paper was accepted for publication in the journal Notes and Records of the Royal Society and the definitive published version is available at https://doi.org/10.1098/rsnr.2020.0051.

\section{LICENCE}

CC BY-NC-ND 4.0

\section{REPOSITORY RECORD}

Jons, Heike, Michael Heffernan, and Dean Bond. 2021. "Unity in Bronze: German Universities and the 250th Anniversary of the Royal Society”. Loughborough University. https://hdl.handle.net/2134/13522085.v1. 
Journal

Notes and Records: The Royal Society Journal of the History of Science

Title

Unity in bronze: German universities and the 250th anniversary

of the Royal Society

Authors

Heike Jöns, ${ }^{1 *}$ Michael Heffernan, ${ }^{2}$ and Dean W Bond ${ }^{1}$

Affiliation

${ }^{1}$ Loughborough University, UK; ${ }^{2}$ University of Nottingham, UK

Full addresses

${ }^{1}$ Geography \& Environment

Loughborough University

Loughborough LE11 3TU

United Kingdom

${ }^{2}$ School of Geography

University of Nottingham

Nottingham NG7 2RD

United Kingdom

*Corresponding author's email address

h.jons@lboro.ac.uk 


\section{Abstract}

This essay explains the emergence of a new era in global science and politics through increasing scientific nationalism on the eve of WWI. Based upon original archival research, we examine how the cultural geopolitics of international scientific jubilees triggered a major change in the selfrepresentation of Prussian and non-Prussian German universities from delivering individual congratulatory addresses to the demonstration of unity through one joint address and present. The analysis focuses on the first centenary of the Royal Frederick University in Kristiania and the quincentenary of the University of St Andrews, both held in 1911, before discussing how all 21 German universities agreed to convey their felicitations with one voice-as Universitates Germaniae-and one address-an inscribed bronze votive tablet-to the Royal Society in London on the occasion of its 250th anniversary as a chartered institution in 1912. We argue that in the context of growing imperial and economic rivalry between European nation states, the politicisation of these jubilees reinforced scientific nationalism and encouraged a unified appearance of German universities overseas, no less than 41 years after the constitution of the German Empire. By analysing changing material, practical, and imaginative resource ensembles in science and politics, we reveal how the geographical imagination of national unity materialised in the German universities' use of bronze tablets for conveying academic appreciation and geopolitical messages in London, and at the Groningen tercentenary in 1914, and thereby heralded a new era characterised by a national university system, an escalation of scientific nationalism, and global wars.

Key words scientific nationalism, cultural geopolitics, jubilees, Royal Society, German universities, bronze tablet 


\section{Introduction}

In the early twentieth century, the international scientific community was shaped by striking ambivalences between scientific internationalism, growing political nationalism, and the celebration of national, institutional, and individual achievements at scientific jubilees. ${ }^{1}$ By examining the amplification of national academic rivalry and competition despite new initiatives for international recognition and cooperation, such as the introduction of the Nobel Prizes in 1901, the first professorial exchange programmes between Harvard University, Columbia University, and the University of Berlin in 1905, and the Solvay Conferences in 1911, this essay contributes new insights to wider academic debates about the emergence and nature of scientific nationalism, understood as 'a closer involvement of science and scientists with national interests and concerns'. ${ }^{2}$ By examining the formation of unity between the 21 Prussian and non-Prussian German universities at the $250^{\text {th }}$ anniversary of the Royal Society in London in July 1912, we identify a major change in academic self-representation that initiated a new era of a working national system of universities-rather than merely an imagined national academic community-and paved the way for war. ${ }^{3}$

Since the early nineteenth century, university academics had been instrumental in shaping forms of German nationalism that propagated the territorial and political union of numerous central European states. ${ }^{4}$ These states were less associated through German-speaking populations than the loose federal organisation of the territorially fragmented Holy Empire 
of the German Nation before 1806, and the more consolidated German Confederation after 1815, both including Austrian lands and leading to a customs union in $1834 .{ }^{5}$ Nationalist sentiments flourished after the defeat by Napoleonic troops in 1806 and centred on university towns and cities. ${ }^{6}$ Students formed fraternities with the aim of advocating national unity, whereas the lectures, writings, and political engagement of professors such as the philosopher Johann Gottlieb Fichte, the theologian Friedrich Schleiermacher, the geographer Friedrich Ratzel, and the sociologist Max Weber provided the intellectual foundations for competing varieties of patriotism, nationalism, and imperialism that shaped German politics during the long nineteenth century in profound ways. ${ }^{7}$ As historians have argued, many professors and student movements supported national unity of the German people based on a liberal constitutional state before the formation of the German Empire in 1871 and a greater anti-liberal and anti-modern nationalism thereafter. ${ }^{8}$ Although a wide spectrum of political and religious student associations existed in the years leading up to WWI, most students subscribed to a pro-monarchist, pro-imperialist, anti-Semitic, and anti-socialist nationalism. ${ }^{9}$

University historians have examined how during the late nineteenth and early twentieth centuries, German universities emerged as role models for the reform of existing institutions of higher learning and the foundation of new research universities across the world, a praxis that involved complex processes of emulation, adaptation, and enhancement of research-related practices. ${ }^{10}$ Sylvia Paletschek has shown that between 
German universities, there had been no diffusion of a common model of the research university. German academic hegemony was rather based on diverse reforms in competing institutions that had already begun before the foundation of the University of Berlin through Wilhelm von Humboldt in 1809-1810. Yet, these humanistic and liberal state institutions were increasingly seen as part of a national system of German universities, shaped by the unifying myth of the Humboldtian tradition as the sole origin of the German research university. ${ }^{11}$

Based on these wider debates about the role of German universities in the development of scientific nationalism and the research university, we contribute to answering the key question of how German universities began to coordinate themselves to act in unity, thereby developing common praxis and identity in a national system of universities. At the fin de siècle, collaboration between German universities had been rare because cultural policy was mostly formulated at the level of federal states and municipalities and regional governments competed for professors to elevate their own universities. ${ }^{12}$ Drawing upon original archival research, we argue that the formation of unity among all German universities is epitomised by the significant change in procedure from providing individual congratulatory addresses at scientific jubilee celebrations to presenting one joint address and present to the Royal Society in July 1912 . We identify the implementation of this new academic praxis as a key moment in the histories of science and the university because this innovation in academic self-representation both 
resulted from and reinforced scientific nationalism in the context of a growing political nationalism on the eve of WWI.

The demonstration of unity among German universities had first been proposed by physicist Woldemar Voigt, Prorektor of the University of Göttingen, ${ }^{13}$ at the Prussian Conference of Rectors in Halle (Saale) in March 1912. Voigt had been keen, as he wrote to fellow university leader and law scholar Karl von Lilienthal in Heidelberg, to generate 'a discussion [emphasis in the original] on the malaise, which had become evident at the recent celebrations, and about possible remedies', citing specifically 'the experiences made in Kristiania and St Andrews'. ${ }^{14}$ Supporting the view of Notker Hammerstein that turning points in university history are less singular events or actions than periods of transition, ${ }^{15}$ we aim to reconstruct how the experiences at the first centenary of the Royal Frederick University in Kristiania and the quincentenary of the University of St Andrews, held within two weeks in early September 1911, contributed to the expression of unity among Prussian and non-Prussian German universities at the Royal Society event in July 1912 . We then discuss resulting developments at the tercentenary of the University of Groningen just before WWI, in press declarations after the start of WWI, and at the inauguration of the University of Frankfurt in October 1914.

The broader interpretive framework of this essay elaborates on Mitchell Ash's notion of 'resource ensembles' from a historical geographical research perspective in order to outline the wider significance of our archival study for existing interpretations of major 
changes in international twentieth-century landscapes of science and politics. According to Ash's understanding, science and politics are not only inextricably interlinked but can be regarded as resources for each other. ${ }^{16}$ Sheila Jasanoff conceptualised the foundational writings of such an integrative science studies approach, especially by actor-network theorist Bruno Latour and political theorist Benedict Anderson on the one hand and historians of science Steven Shapin and Simon Schaffer on the other, with the two idioms of 'constitutive' and 'interactionist' co-

production. Both notions of co-production share an interest in researching how representational practices are employed in the interaction of science and politics to constitute scientific authority and political power, with a focus on the making of discourses, representations, institutions, and identities. ${ }^{17}$ Ash's typology of resources for identifying continuity and change in these intertwined histories of science and politics understands the notion of 'resources' also in a broad sense, mentioning explicitly cognitive-conceptual, epistemological, discursive, rhetorical, practical, personnel, infrastructural-institutional, financial, and contextual dimensions. ${ }^{18}$

We draw upon triadic thought in the form of a triadic actor-network approach to capture Ash's and Jasanoff's dimensions of interest at the science-politics nexus through three main types of entities constitutive of resource ensembles. These three types of entities account for material, practical, and immaterial changes in resource ensembles and contributein conjunction with each other-to major reconfigurations in science and 
politics. ${ }^{19}$ By interweaving the historicity of a material-semiotic artefact, in the form of a bronze tablet cast on behalf of all German universities, with the related socio-practical change of academic self-representation by individuals and institutions at scientific jubilees, and the geopolitical meanings as well as affective registers of the imaginative-discursive concept of German national unity, we identify changing resource ensembles on the eve of WWI that heralded a new era in science and politics. We show that the start of this new era was characterised by a proliferating exchange of geopolitical messages and bronze plates in science and higher education, the institutionalisation of annual non-official all-German Rectors' Conferences, and a widely communicated unity between German academia and the German army in WWI.

The following narrative explicates this major change in scientific and political resource ensembles by responding to three research questions: Why did the university jubilees in Kristiania and St Andrews contribute to the manifestation of a national identity among German universities on the eve of WWI? How did the German universities present themselves when conveying their joint felicitations to the Royal Society in London? And what were the reactions to and wider outcomes of the German university delegations' display of unity in the Royal Society? To answer these questions, the first part of this essay reviews critical scholarship on jubilees in the context of the internationalisation of science and higher education, as well as upsurges of scientific nationalism, and provides an overview on our historical geographical approach and sources. The second and third parts outline the cultural geopolitics of the university jubilees in 
Kristiania and St Andrews before reconstructing the Royal Society's anniversary event in the fourth part. By cultural geopolitics we mean the ways in which geopolitical power relations interlink with cultural expressions, including ideas, values, and identities; discourses, representations, and symbols; settings, practices, and performances. ${ }^{20}$ The fifth part discusses the proliferation of bronze tablets and other major consequences of German academic unity; and the sixth part concludes by reflecting on the wider meaning of this significant episode for the histories and geographies of science and the university.

\section{The nature and politics of scientific jubilees}

Celebrations of the foundation of universities and learned societies have a long history with early modern precedents. ${ }^{21}$ Before the proliferation of international scientific conferences in the decade preceding WWI, such jubilee celebrations provided the main opportunities for researchers and academics to engage in international and intersectoral networking with representatives from universities and scientific institutions near and afar, as well as dignitaries and other professionals from the worlds of politics, business, and culture. ${ }^{22}$ Often spanning several days of festivities and events, involving institutional members, local populations, and visitors, scientific jubilees exhibited considerable geographical reach, significance, and impact by supporting the formation of multiple scientific, cultural, and political identities at the levels of the university, the city, the wider region, the state, and often also supranational geopolitical alliances. ${ }^{23}$ 
University jubilees thus served important political, economic, cultural, social, and academic interests, provided the contexts in which celebratory university histories were written, and contributed to both the internationalisation and nationalisation of science and higher education. ${ }^{24}$

The consideration of changing geopolitical alliances and warfare is of particular importance when examining to what extent academic and political interests aligned or clashed before, during, and after the staging of university jubilees, and how such events impacted on international and national positionings and networks. Focussing on Nordic countries, the majority of essays published in two books edited by Pieter Dhondt have shown how university jubilees encouraged increased Nordic cultural and scientific cooperation, especially in the period between the Second Schleswig War (1864), in which Denmark was unsupported by its Nordic allies when fighting against Prussian and Austrian troops over Schleswig, ${ }^{25}$ and the end of the union between Sweden and Norway (1905), which contributed to the celebration of Norwegian national agendas and German connections at the university centenary in Kristiania. ${ }^{26}$ Yet, as the essays by Robert Anderson on four Scottish university jubilees (1884-1911) and by Guðmundur Hálfdanarson on the opening of the University of Iceland (1911) have argued, the celebrating universities often struggled to reconcile their expected roles as both national and cosmopolitan institutions. ${ }^{27}$ This included the University of St Andrews, whose quincentenary is pivotal for understanding why German 
universities unified to provide a joint congratulatory address and present to the Royal Society in London in 1912.

The interplay of academic cooperation and competition between individuals, institutions, and nation-states has also varied by historical and geographical context. Drawing on the examples of the quincentenary of the University of Leipzig in 1909 and the centenary of the University of Berlin in 1910, two German jubilees that celebrated the scientific achievements, national prosperity, and political unity of the German Empire, Sylvia Paletschek has stressed the 'severe competition among universities in terms of an exuberant staging of the jubilee since all of them sought to profit from this event in the competition for students, professors, financial resources and public attention'. ${ }^{28}$ Situated in the centre of the German Reich's vibrant capital, the University of Berlin attracted considerable international attention with its first centenary in October 1910, which the local organizing committee used for legitimizing the German Empire's constitutional monarchy. ${ }^{29}$ In the wider context of growing German nationalism based on 'Prussian, Protestant, and conservative sources' that marginalised 'Catholics, Jews, and political radicals', ${ }^{30}$ Paletschek has argued that the Berlin centenary was pivotal for creating 'the Humboldt myth', the Prussian bias that condensed the history of nineteenth-century German universities into the University of Berlin's 'national success story', which 'was (unconsciously) designed for the purpose of identity formation'. ${ }^{31}$ 
Our historical geographical analysis of the three events that encouraged the overseas demonstration of national unity among German universities within two years after the Berlin centenary emphasises geopolitical discourses, practices, and representations as resource ensembles that politicised scientific jubilees. At the same time, we scrutinise the imaginative, practical, and material consequences of choosing an inscribed bronze votive tablet as a joint present from all German universities to the Royal Society. Methodologically, we use textual analysis, secondary data analysis, and thematical mapping as three research methods for analysing three types of primary and secondary sources, namely hitherto unused archival documents, such as correspondences, meeting minutes, and congratulatory addresses from the archives in the universities of Heidelberg, Göttingen, St Andrews, Groningen, and the Royal Society; published proceedings of the jubilees; and related academic literature.

\section{Debating cultural politics in Kristiana}

When the Royal Frederick University of Kristiania celebrated its first centenary in the late summer of 1911 , an impressive range of international visitors attended the event in the capital city of the politically neutral nation of Norway. ${ }^{32}$ Half a century earlier, the university's fiftieth anniversary in 1861 had emphasised the ideals of scientific universalism over state politics at a time of crisis between the united nations of Sweden and Norway. Yet, Johan Nicolai Madvig, the senior delegate from 
the University of Copenhagen and a high-ranked Danish politician, had used the final evening dinner as an opportunity for promoting political interests that tried to claim Slesvig (in German, Schleswig) for Denmark. ${ }^{33}$ The two duchies of Schleswig-Holstein had been ruled by the Danish king in personal union since 1460 but for some time been affected by Danish and German populations quarrelling about the joint constitution. In response to Gustav Thaulow's evocation of 'a Germanicprotestant scientific community' across Germany, Denmark, Sweden, and Norway, delivered on behalf of the German-speaking University of Kiel in Holstein, 'a centre of opposition to the Danish attempts to separate Schleswig from Holstein', ${ }^{34}$ Madvig insisted that

The true academic community was limited to those with whom we can communicate without an interpreter, and the present representatives of the University of Kiel could not be part of this community. ${ }^{35}$

By 1911, Schleswig-Holstein had been a part of Prussia since the Danish defeat to Prussia and Austria in 1864 and belonged to the unified German Empire. At a time when German universities were at the height of their international reputation and influence, the Royal Frederick University's first Rector Waldemar Christopher Brøgger, an internationally well-respected and widely networked geologist, ${ }^{36}$ made the controversial decision to select German as the centenary meeting's prime language. 
Given that the Royal Frederick University had shunned the classics at its foundation in the context of a nationalisation of the sciences, Latin had not been an option, and Norwegian would not have been understood by most international delegates. ${ }^{37}$ Brøgger had also been impressed by the monumental centenary celebrations in Berlin (1910), an event during which Emperor Wilhelm II announced his plan to realise Wilhelm von Humboldt's suggestion of founding specialised research institutes by creating the umbrella organisation of the Kaiser Wilhelm Society for the Promotion of Science (1911). ${ }^{38}$ This experience shaped Brøgger's twofold interest in using Kristiania's academic centenary for stressing the university's significance in Norwegian nation-state building and promoting state-funded research within and beyond the university. ${ }^{39}$ Consequently, German was chosen over English and French as the centenary's lingua franca, even though the invitations were sent out in Latin. ${ }^{40}$

The main centenary festivities in Kristiania, a city of about 242,000 inhabitants, took place over four days from 4 to 7 September 1911 . This international part of the event included a dinner hosted by the King of Norway, Haakon VII, in the Royal Castle and offered an optional train excursion to Bergen (8-10 September). ${ }^{41}$ The first full day of ceremony on 5 September began with a lecture by Rector Brøgger in German, followed by delegates providing felicitations and addresses from 130 overseas institutions. ${ }^{42}$ These overseas institutions practiced five main ways of honouring the celebrating institution, in the following order of effort and appreciation: first, by sending a delegate to present a physical 
congratulatory address; second, by sending a delegate to convey verbal felicitations; third, by nominating a delegate from a different institution to hand over a physical congratulatory address or verbal felicitations; fourth, by posting a congratulatory address; and fifth, by sending a telegram. In the context of a growing academic community, both national and imperial dimensions had become important ordering mechanisms at jubilees such as the Kristiania centenary, where overseas institutions were grouped according to the countries' geographical positions into twelve delegations that were asked to choose one speaker each. ${ }^{43}$

The largest European presence was exhibited by the German Empire, which was represented by 18 universities (all but the southern German universities of Erlangen, Gießen, and Munich) and six learned societies and scientific institutions. This amounted to five more institutions attending from the German Empire than the United Kingdom, with eleven universities and eight other institutions conveying felicitations and addresses. There were still two more German than British institutions represented when adding the universities in Adelaide, Melbourne, and Montreal that attended from across the British Empire. Yet, a shift in transatlantic power relations was underway because the German Empire was represented by eight institutions less than the emerging economic and academic hegemon of the United States of America, with delegates from 25 universities and seven other institutions. The larger presence of overseas institutions in Kristiania than in St Andrews exemplifies the appreciation shown to this neutral country by institutions from the United 
States and Argentina, Sweden and Denmark, the German Empire and Austria-Hungary, as well as the United Kingdom and Russia, including more than twice as many learned societies (Figure 1).

[Please insert Figure 1 about here]

According to Jorunn Sem Fure, newspaper reports on the celebrations in Kristiania were highly critical about the dominance of the German language during the event. Even the German press thought that the German speakers should have less often characterised the host university as 'Germanic' and more often referred to its 'Norwegian', 'Scandinavian', and 'Nordic' cultural embeddedness. The Germans' condescending habit of regarding Norway's main university as a 'North Germanic provincial university' caused the Norwegian newspaper Aftenposten to criticise the university leadership's preference of German over English when choosing the jubilee's main language. ${ }^{44}$ Rector Brøgger and the academic senate of the Royal Frederick University reacted to these struggles over language and German dominance by conveying their sincere thanks to all those institutions that had honoured the university during the centenary celebrations in French. ${ }^{45}$

\section{Politicising academic culture in St Andrews}

In the week after the university jubilee in Kristiania, the international academic community gathered in St Andrews, a small university town of 
only 7,851 inhabitants, characterised by picturesque ancient ruins along the wild, romantic scenery of the eastern Scottish seashore. Some visitors, like Voigt from Göttingen, arrived directly from Bergen, with Sunday and Monday as days of travel between the two jubilees. ${ }^{46}$ The visitors were entertained from 12 to 15 September, enjoying an evening reception, two main days of ceremony, and one day in Dundee. ${ }^{47}$

The first full day of ceremony saw the presentation of addresses to the Chancellor, Lord Balfour of Burleigh, in front of over 3,000 attendees. ${ }^{48}$ This most significant ceremonial praxis of providing recognition to the host institution was launched by a short welcoming message read by the Chancellor on behalf of King George $V$ followed by the Chancellor's address. In his speech, Lord Balfour of Burleigh, a Scottish unionist and free-trader, former Secretary for Scotland, and President of the 1910 World Missionary Conference in Edinburgh, consciously politicised the event by stressing his nation's demand for governing and defending the British Empire to secure 'national liberty, of which our Empire is the type', and by providing the subsequent provocative statement about British imperial expansion:

The Empire will widen, and will require a new and deeper sense of individual responsibility on the part of all those who try to do her service, while sound constitutional government must remain the object of our veneration, and is not to be made the plaything of hazardous experiment. ${ }^{49}$ 
Lord Balfour of Burleigh's assertion set the scene for feelings of resentment among the delegations of rivalling nation-states that found themselves in the middle of the Second Moroccan Crisis. This crisis had brought France and the UK close to war with the German Empire over imperial interests in North Africa in early July 1911 and was about to reinforce the Anglo-German navy race as well as to shift of the German Empire's attention to its neglected army. ${ }^{50}$ Lord Balfour of Burleigh's words fomented these geopolitical tensions and could thus not have provided a greater contrast to the laudatory spirit of the felicitations and addresses subsequently presented to the Chancellor by 100 delegations from 85 overseas universities, grouped by country and introduced with the national anthem, followed by 15 learned societies from overseas, including the dominions.

Characterised as 'a lengthy but interesting ceremony', during which some delegates delivered short speeches, whereas others only presented their institution's printed address to the Chancellor, a further 66 institutions had sent delegates to convey their compliments of home universities (17), learned societies in Britain (35), University General Councils (3), town councils and local institutions (7), and churches (4). ${ }^{51}$ The geographical representation of overseas institutions reveals that the German delegation was the largest (20 percent), followed by the United States with three fewer institutions (17 percent). A relatively large contingent of institutions from British imperial territories in Africa (4 percent) and the Asia Pacific region (12 percent), especially from India 
and Australia, honoured the third oldest university in the British motherland (Figure 1). St Andrews hosted three more institutions from France than Kristiania did, thus doubling its share to 8 percent (Table 1).

[Please insert Table 1 about here]

The second day of ceremony was used for the award of 100 honorary doctorates, including the bestowing of an LL.D. on the Liberal British Prime Minister Herbert Henry Asquith (1908-1916) and the honouring of twelve German, six French, and four American participants. ${ }^{52}$ This function was repeatedly interrupted by students shouting 'No Latin!' and mocking the awardees through jokes and song excerpts. According to the cultural historian Karl Lamprecht from Leipzig, who compared his experiences at St Andrews' quincentenary to the more orderly jubilee proceedings in Kristiania, these spontaneous 'Celtic' student outbursts created a peculiar atmosphere combining the grotesque and burlesque with the worthy and sublime. ${ }^{53}$

Lord Rosebery, the Lord Rector of St Andrews University and former Liberal British Prime Minister (1894-1895), delivered two speeches-the Rectorial address on the morning of 14 September, before the award of the honorary degrees, which focused on the history of the university, and a shorter address during the reception at University College Dundee on 15 September. During the latter, he expressed the agony felt by many delegates over the numerous toasts and speeches-some intricately 
drafted in Latin-, by joking that during the eighty to one hundred speeches he had heard on the first day, 'occasional surprises of eloquence were vouchsafed to them', but he would promise to keep his second speech brief. Lord Rosebery released a few more rhetorical attacks on what he regarded as an escapist antiquity-loving academic world by telling an anecdote about his previous experience of addressing a large audience at a political event in Dundee for an hour, after which Sir Henry Campbell-Bannerman, a more senior liberal politician and British Prime Minister from 1905 to 1908 , told him over supper the story of the old and the young minister. The moral of this story was that the old minister did not praise the eloquent sermon of the ambitious young minister but instead commented that he must be very proud 'to have got rid of all that weary, windy, wasteful trash aff your stammick'. ${ }^{54}$

At the subsequent luncheon with over 600 guests in Dundee's Drill Hall, presided over by Chancellor Lord Balfour of Burleigh, the first toast of 'the university' was given in English by Louis Cazamian, Professor of English Literature in Paris, who praised the ability of the French 'to renew themselves too completely, to lose, though with some reticence, some of the memories of the past', emphasizing that the warm welcome in St Andrews for the French delegation 'would find a grateful echo in the countrymen at home, whatever might be said to the contrary'. ${ }^{55}$ Press reports of this toast evoked L'Entente Cordiale (1904), signed between Britain and France to improve bilateral relationships and settle imperial rivalry overseas in similar ways as the subsequent Anglo-Russian accord 
(1907), thus alluding to a geopolitical situation in which the central powers of the German Empire, Austria-Hungary, and Italy, linked by a Triple Alliance of mutual support since 1882, found themselves surrounded by the Triple Entente of Britain, France, and Russia. ${ }^{56}$

The last toast of 'the guests' was provided by Heidelberg's Rektor Friedrich Carl von Duhn, a classical archaeologist who had presented his university's address in Latin. ${ }^{57} \mathrm{He}$ contented himself with expressing the hope and belief that the 'splendid example' Dundee had given 'to the rich people of Europe [...] would be useful in providing for the promotion of the general education of the people'. ${ }^{58}$ Lord Rosebery had already left Drill Hall 'before the short toast-list had been exhausted', probably wanting to avoid listening to yet another German classical scholar and instead sail southwards on his steam yacht Zedia, which had anchored in St Andrews Bay together with warships. ${ }^{59}$ In regard to the evening return by train, commentators noted the overrepresentation of French compared to German and Italian, which implies that many German delegates, including Voigt, who travelled back to Göttingen on 15 and 16 September, were also on their journey home. ${ }^{60}$

In his brief report on both jubilees to the Minister of Intellectual and Educational Affairs, August von Trott zu Solz, who had just standardised the 45-minute teaching hour across all German schools, had contributed to the foundation of the Kaiser Wilhelm Society earlier in the year, and was about to play a key role in the foundation of the civic University of Frankfurt in 1914, Voigt did not mention any negative experiences but 
stated explicitly that he was pleased 'to see that Germanism played the first role in Kristiania, to such an extent that Rector Brögger gave his main speeches in German'. The lingering rivalry with French colleagues was evidenced by Voigt's subsequent sentence, when emphasizing that in St Andrews, the German delegates were also greeted in a remarkably friendly way and 'by no means set back behind the French'. Even the unequal number of honorary degrees awarded to twelve German and only five French delegates, among them Voigt himself, was mentioned to reassure the Minister that 'any political demonstration has been carefully avoided'.61

The geopolitical tensions evident at the university jubilees in Kristiania and St Andrews found their main expression in anti-German sentiments in the press and verbal attacks by two British Lords. Voigt's suggestion to demonstrate unity among all German universities at the $250^{\text {th }}$ anniversary of the Royal Society thus appears to be his response to these jubilee experiences, and especially to Lord Balfour of Burleigh's provocation about future British imperial expansion. In the context of the Second Moroccan Crisis, even the German Social Democrats aligned themselves with the idea of war when passing at their party congress a resolution about the Moroccan question, presented by the well-known internationalist August Bebel on 14 September 1911. This resolution clarified that the Social Democrats would prefer a peaceful solution to conflicting international colonial interests but would support the defence of German economic interests in association with the rest of the German 
population, if the ruling classes in France and England continued their expansionist and monopolist colonial policy. ${ }^{62}$

Further stimuli for the subsequent formation of German academic unity were most likely provided by two announcements published in the British scientific journal Nature in early November 1911: first, the programme for the Congress of the Universities of the Empire on 2-5 July 1912, aiming to facilitate exchange and coordination among 51 British universities at home and overseas; and second, an update on the state of military aviation by the War Office, detailing the certified skills of trained pilots and the types and conditions of British war aeroplanes. ${ }^{63}$ Combining pragmatism, through the reduction of the great effort required for producing numerous congratulatory addresses, with scientific nationalism expressed by unity, Voigt decided within six months after the university jubilees in Kristiania and St Andrews that he needed to convince all German universities-Prussian and non-Prussian-to change the academic habit of delivering individual addresses at scientific jubilees and reinforce the increasing entanglement of science and politics by demonstrating German unity overseas.

\section{Practicing German nationalism in The Royal Society}

The invitation to the $250^{\text {th }}$ anniversary celebrations in the Royal Society, composed in Latin and dated 8 January 1912, was signed by the Society's President, the geologist Sir Archibald Geikie, and arrived in the University of Göttingen on 22 January. ${ }^{64}$ One month later, on 22 February 1912, the 
senate decided that its Prorektor Voigt would represent the university at the Royal Society's jubilee in London. ${ }^{65}$ Having communicated this decision in German to the Royal Society before the end of the month, Voigt used the Prussian Conference of Rectors in Halle on 10-12 March 1912 to propose that a joint address and present from all German universities be delivered to the Royal Society in London. ${ }^{66}$ Originally aiming to stimulate a discussion about the experiences in Kristiania and St Andrews regarding the presentation of 15-18 congratulatory addresses by German universities and to overcome the fragmentation of the German delegation at similar events in the future, Voigt himself was surprised that the Prussian university leaders immediately agreed to go ahead with his twofold proposal. ${ }^{67}$

Based on this mandate from the Prussian Conference of Rectors, unity between Prussian and non-Prussian universities in the German Empire was to be achieved in two steps. In a first letter to all nonPrussian universities, dated 13 March 1912, the gynaecologist Johann Veit, Rektor of the University of Halle-Wittenberg and Chairman of the Prussian Conference of Rectors, wrote to all academic leaders of the nonPrussian German universities to ask informally what their universities' senates thought about the two ideas proposed at the recent Prussian Conference of Rectors in Halle-first, to select a speaker amongst the German universities for university jubilees, who should not always be the delegate of the University of Berlin or the oldest German university but someone with relevant language skills, a special relation to the 
celebrating institution, or of particular eminence; and second, to give a collective present rather than individual addresses that would often receive little attention. 68

The overwhelmingly positive responses enabled Voigt to write a second letter to the academic heads of all 21 German universities, dated 25 April 1912, in which he invited their institutions to participate in a joint address and present for the Royal Society in London. Voigt explained the reasoning behind his proposal as follows:

The usual individual addresses, whose number often reached 150180 during large festivities, whose drafting requires a considerable amount of work, whose delivery is a tiring act, and whose fate is immediate oblivion, was generally recognised as unsuitable. ${ }^{69}$

Similarly to the speeches, the often intricately designed printed addresses would easily be forgotten, and thus Voigt made the case for providing a solid material representation of the German universities' appreciation for the Royal Society in the form of an engraved bronze tablet, about which he had consulted with a metal goods company in Württemberg already in mid-February 1912:

It was also agreed [...] trying to win over the senates of all universities in Germany [emphasis in the original] for the presentation of a single joint bronze votive tablet, which is intended 
to be mounted on the wall in one of the rooms of the academy and thus would be suitable to represent both a decoration and a memento. ${ }^{70}$

The great advantage of such a bronze tablet was not only a more visible and durable commemoration of the Royal Society's scientific prowess but also the permanent representation of German universities in one of the most renowned international centres of scientific achievement. Asking for a prompt response, Voigt underlined the political meaning of his approach and requested that colleagues refrain from criticising details:

A unanimous solidarity of all German universities should not be entirely without political significance at the present time and it is hoped that especially in regard to this point, complaints about details of the project might be deferred. ${ }^{71}$

The responses to Voigt's letter confirm that his proposal for a joint congratulatory address and present was informed by growing German nationalism and the related desire of northern and southern German universities to demonstrate unity overseas. In the University of Kiel, Voigt's plan was simply 'received with the liveliest applause', ${ }^{72}$ whereas law scholar von Lilienthal, the Rektor of the University of Heidelberg, conveyed his university's willingness to participate in a joint present for the Royal Society because he and his colleagues thought that especially in 
this case, a concerted appearance of all German universities would seem to be most appropriate. In the context of growing animosities with England, von Lilienthal issued the following plea:

We urge, if against our hope it would not be possible that all German universities reached an agreement, that then also the Prussian universities would refrain from working together and keep the usual procedure. It would be extremely unedifying at this very moment in time to convey the impression in England of a fragmentation between Prussian and non-Prussian universities. ${ }^{73}$

Only two years before the outbreak of WWI, the academic heads of two other German universities-Freiburg and Rostock-argued along similar lines. Breslau insisted that its senate would need to make a new decision, if only the Prussian universities united, and Munich also only agreed on the condition that all German universities would participate. ${ }^{74}$ In contrast, the academic leaders of the Prussian universities in Berlin, HalleWittenberg, and Königsberg wrote that their universities would be fine with a unified appearance of either the German or at least the Prussian universities. Veit from Halle-Wittenberg even added that his university was prepared to make a double contribution, if only the Prussian universities participated in the joint present. ${ }^{75}$

Notwithstanding their slightly differing perspectives, all 21 German universities had agreed on a joint approach for the Royal Society's $250^{\text {th }}$ 
anniversary within one month. ${ }^{76}$ Yet, the rectors of the old universities of Heidelberg, Leipzig, Würzburg, and Rostock emphasised that they did not want to be co-opted or patronised permanently and preferred to make an autonomous decision in the future. ${ }^{77}$ The universities' century-long loyalty to kingdoms, duchies, principalities, and free cities meant that regional and institutional identities-sometimes beyond the difference between Prussian and non-Prussian universities-complicated the development of a German national identity and cultural policy. Regarding future collaborations, von Lilienthal suggested either joint debates and decisions at an all-German Conference of Rectors or the appointment of a special commission of representatives from Prussian and non-Prussian universities that would make suggestions to all German universities, a twofold proposal that received broad support. ${ }^{78}$

The cultural geopolitics of the bronze tablet

The idea to present a bronze tablet instead of a printed address at jubilee celebrations had its precedents. When serving as the Rektor of the University of Leipzig in 1910-1911, Lamprecht publicly exhibited several addresses and presents, which his university had received on the occasion of its quincentenary celebrations in 1909 , together with artefacts representing the progress of American higher education. ${ }^{79}$ Among these presents were a gold shrine from the German University of Prague, containing a silver cast of its first seal, and six bronze plaques from the imperial court in Leipzig, the royal Saxon government and the three 
colleges for technical sciences, veterinary sciences, and the arts in Dresden, and the Association for the Fostering of German Science, Arts, and Literature in Bohemia. ${ }^{80}$ Designed by Karl Groß, the Director of the Dresden School of Applied Arts, the bronze relief from the Technical College of Dresden depicted university history as a struggle between good and evil framed by the curiosity of youth and the wisdom of the elders. ${ }^{81}$ All six bronze casts probably encouraged Lamprecht, who attended-like Voigt-both jubilees in Kristiania and St Andrews, to offer to these universities a small bronze plaque engraved in German instead of a printed address, which in turn helped most likely to inspire Voigt's subsequent initiative to materialise the idea of German unity in bronze. ${ }^{82}$

Voigt had emphasised in his original letter to all German universities that the committee overseeing the project regarded a neutral design, without any allegorical figures, as most appropriate for ensuring the approval by the senates of all universities in the German Empire. Since English academic bodies always preferred antique ornamentation for their buildings, he argued that the aesthetically most pleasing design for this tabula gratulatoria would certainly need to draw upon valuable antique models, and therefore the committee had reached an agreement to adopt the motif of the corona civica (Figure 2). ${ }^{83}$ Voigt's first circular letter had included a draft of the bronze tablet to be cast by Magdeburg artist Professor Rudolf Bosselt, the Director of the city's School of Arts and Crafts, who was internationally renowned for his exhibition of medals at the World's Fair in Brussels in 1910. ${ }^{84}$ The corona civica was represented by a wreath of oak leaves, with a bow tied at the bottom of the wreath, 
and occupied the upper three fifths of the bronze tablet. The tablet was framed in its corners by four tiny roses hiding the mounting screws, signed by Bosselt to the left of the bottom right rose, and showed the following engraving in Latin within and beneath the wreath:

To the British Royal Society, the illustrious cultivator and protectress of the Sciences. On the happy completion of 250 years. Warm congratulations from the German universities. AD $1912^{85}$

[Please insert Figure 2 about here]

The motif of corona civica, or 'civic crown', had been used in ancient Roman civilisation for recognising military, political, and civic achievement. Most famously, Roman Emperor Augustus received the honour of corona civica in $27 \mathrm{BC}$, the year in which he ascended to power, 'because he had saved the state and its citizens after decades of civil wars'. Yet, the corona civica was also awarded to Roman citizens for their military achievements and political loyalty. ${ }^{86}$ Voigt's committee probably adopted this ancient motif as a representation of honour and excellence because he called the finalised tablet a 'carefully crafted piece of art worthy of the occasion'. ${ }^{87}$ 
The classically educated scientists and scholars, ridiculed by Lord Rosebury in St Andrews, may have been aware of further historical connotations of the corona civica. This ancient motif could have either implied that the German universities assumed authority to grant the Royal Society an honour as one of the citizens of 'their' international academic community or-in response to Lord Balfour of Burleigh's provocative statement 'The Empire will widen'-been used as a critique of the Royal Society's role in shaping the British Empire, for example, by drawing parallels with imperial Rome. British global economic and political dominance, combined with growing international competition in industrial production and world trade, had certainly reinforced German nationalism, as well as Emperor Wilhelm II's military ambition to rival England's naval power. ${ }^{88}$ Demonstrating 'unity in bronze' thus conveyed a sense of scientific nationalism that despite the warm congratulations aimed to evoke the geographical imagination of a united German front. ${ }^{89}$

Geopolitical considerations also played a role in discussions about the engraving of the bronze tablet. The retired physicist Professor Georg Hermann Quincke, a foreign member of the Royal Society since 1879, had been chosen to represent the University of Heidelberg in London and proposed that the names of the participating universities be inscribed on the backside of the bronze tablet. ${ }^{90}$ In his response, Voigt clarified that putting the names on the back would be ineffective because the tablet was meant to be hung on the wall and no one would see the backside. Listing individual institutions on the front was also inadvisable since this 
would detract from the unity that German universities sought to present through their common action. ${ }^{91}$ Voigt's deliberations about the tablet therefore included quite explicitly the geopolitical meaning of different designs, whereas von Lilienthal insisted that the names of the participating universities 'could be of historical interest', especially if the bronze tablet would be taken off the wall. ${ }^{92}$

The event

The $250^{\text {th }}$ anniversary of the Royal Society in London was hosted by Sir Archibald Geikie, President of the Royal Society from 1903 to 1913. Geikie was an accomplished geologist, who had published several books on geology and physical geography since the 1850 s and held numerous significant posts during his distinguished academic career. Most importantly, Geikie had served as the Director of the Geological Survey of Scotland, held the Murchison Chair of Geology and Mineralogy at the University of Edinburgh, and was Director-General of the Geological Survey in London. Before he became the Royal Society's president, he also acted as Foreign Secretary of the Royal Society, President of the British Association for the Advancement of Science, President of the Geological Society, and Secretary of the Royal Society. ${ }^{93}$

Geikie was fond of French language and culture. He had sympathized with the French during the Franco-German war of 1870, and one year later, he married Alice Gabrielle Pignatel, who had grown up in France. In 1894, Geikie thought he might have alienated some of his 
German colleagues when presenting a paper in French as the official conference language at the International Geological Congress in Zurich. Geikie read out the written French version as planned, although his German peers had urged him to speak in English or German. His impression was that the French and Swiss members were pleased with his performance, but he was not sure if some of his German associates quite forgave him, commenting that this incident 'was not the only sign of the German jealousy of France, even among students of science'. ${ }^{94}$

On 5 July 1912, Voigt informed Geikie, once more in German, of the German universities' plan to deliver one joint address and present to the Royal Society. ${ }^{95}$ Geikie tried to accommodate all requests by Voigt on behalf of the German delegation, despite his general perception of a certain 'narrowness, vanity, and self-assertion, unhappily so prevalent in German professorial circles'. ${ }^{96}$ Robert William Frederick Harrison, the long-term Assistant Secretary of the Royal Society, thus reassured Voigt that an easel would be provided 'to be placed near the President's seat at the presentation of Addresses on the $16^{\text {th }}$ instant, to hold the bronze Tabula', and that the President 'consents very willingly to the unveiling being part of the ceremony on Tuesday afternoon' ${ }^{97}$

Geikie recalled that the celebration of the Royal Society's $250^{\text {th }}$ anniversary was the 'most outstanding incident' during his decade-long presidentship. ${ }^{98}$ The celebrations lasted for four days from 15 to 18 July 1912 and saw 132 universities, learned societies, and scientific institutions from overseas presenting addresses through delegates. The 
Royal Society event was honoured by more overseas institutions than the recent university jubilees in Kristiania (130) and St Andrews (100), which illustrates the high international significance and reputation of the Royal Society for both universities and learned societies. ${ }^{99}$ The geographical origin of represented institutions was very similar to St Andrews but the power-relations had again shifted away from hegemonic German academia, with the United States outnumbering German institutions by three, after having been three institutions short in St Andrews. France increased her presence in London by four institutions, whereas Africa and the Asia Pacific region also delivered more institutional addresses than in St Andrews but reduced and held their shares, respectively (Table 1). Geikie was full of praise for this 'world-wide brotherhood, inspired by one common spirit of devotion to the study of nature'. ${ }^{100}$

The event's programme began with an evening reception in Burlington House on Monday, 15 July. The first full day entertained with a service in Westminster Abbey, the reception of delegates with the presentation of addresses in the Society's Great Library, and a Banquet in the Guildhall of the City of London. In lieu of the award of honorary degrees by the Royal Society (six each were conferred by Oxford and Cambridge on 19 July), the second full day saw guided visits to six places and institutions in London, a garden party, and The Royal Society Conversazione, with objects of scientific interest on display in Burlington House. On the final ceremonial day, a similar choice of guided visits as on the day before preceded a garden party in Windsor Castle hosted by King 
George V and Queen Mary, followed by several evening dinner parties. On Friday, 19 July, there was an option to join excursions to Oxford or Cambridge. For Voigt, 'all parts of these festivities provided unforgettable impressions'. ${ }^{101}$

\section{Voigt's speech}

The formal reception of the visitors took place in the Great Library of the Royal Society on the afternoon of 16 July. Geikie had applied the plan of the German universities to provide one joint speech to all countries, whose delegates were asked to choose one representative to give a short speech of up to three minutes in English on behalf of all delegates from the respective country, even if each university and learned society might still present separate congratulatory addresses in writing. ${ }^{102}$ The number of delegates was simply too large for individual speeches, given that 132 overseas institutions were present.

Voigt delivered the joint congratulations of German universities and learned societies next to an easel holding the veiled bronze tablet. This present had a size of $70 \mathrm{~cm} \times 100 \mathrm{~cm}$, weighted c. $25 \mathrm{~kg}$, and had been brought over by him as passenger luggage. ${ }^{103}$ Voigt first expressed the admiration that members of the German delegation held for the achievements associated with this remarkable scientific institution:

I have the honour to convey to you the congratulations of the Academies and the Universities of Germany. The large number of 
delegates present here bears witness to the high admiration which they feel for your glorious Academy. ${ }^{104}$

After emphasising that attendance at jubilee celebrations showed appreciation for the hosts, Voigt conveyed his deep gratitude for the benefits that have arisen from the Society's work for German education and learned culture, but he did not do so without drawing attention to the latter's recent rise to international prominence:

the Royal Society has become an influential teacher of all cultured nations, and a teacher of the German Academies and Universities too, which unfavourable conditions long prevented from attaining their proper rank in Science. For this reason we wish not only to offer our congratulations, but also to express our gratitude to the Royal Society. ${ }^{105}$

When introducing the bronze tablet, which he unveiled at the end of his speech, Voigt explained that the German academies-that had not been mentioned in the correspondence of the universities about the bronze tablet-would follow the traditional procedure of separate addresses. Yet, Voigt made clear that all German universities were united in honour of the Royal Society: 
The German Academies following the old academical form have prepared separate Adresses [sic], which the delegates shall present themselves. But the Universities desiring to do justice (as far as possible) to the importance and the renown of the Royal Society, which 'aere perennius' [longer lasting than bronze] will endure, have united in presenting this brass tablet. The classical device of the 'Corona civica' which adorns it, points to the benefits which the Royal Society has conferred upon mankind. 106

Voigt then addressed the President of the Royal Society with all German directness and requested-presumably quite bluntly for British tastesthat the bronze tablet be put on display:

We beg the President of the Society to grant our 'tabula gratulatoria' a place on the wall of one of these rooms so rich in memorials. ${ }^{107}$

Once on display in the Royal Society, the physicist Voigt concluded, the bronze tablet would signify a global academic community, emphasising unity, harmony, and collaboration in knowledge production over division, quarrels, and competition. At the same time, he alluded to German leadership by speaking of 'an other' global invisible college:

if Robert Boyle characterised the beginnings from which the Royal Society arose as the "Invisible College", our tablet will bear witness 
that an other "Invisible College" now stretches over the whole earth: the unity of all those which work harmoniously together at the task whish [sic] the Royal Society set before itself two hundred and fifty years ago: "the Improvement of natural knowledge by experimental research"'. 108

Couched in celebratory terms, one can only speculate how the British hosts and jubilee delegates felt about this unified appearance of German universities at the height of their hegemony and their demand for a permanent presence in the halls of Burlington House. In the context of animosities between the French and German delegations at previous overseas jubilees and President Geikie's reactions during the editing process of the jubilee proceedings, as discussed further below, delegates will certainly have sensed some of the ambiguities inherent in Voigt's choice of words between the celebration of scientific internationalism and the pursuit of national interests beyond the academy. This assumption is confirmed in Voigt's report to August von Trott zu Solz, the Minister of Intellectual and Educational Affairs in Berlin, wherein he stressed that 'the political significance of the unity of all German tribes has, as inferred from private remarks, been felt strongly'. ${ }^{109}$

Voigt's speech and report need to be evaluated in the context of written contributions by British and German politicians, intellectuals, and business leaders in the German cultural journal Nord und Süd published just before the Royal Society's anniversary event in June and July 1912. 
The new editor of Nord und Süd, Ludwig Stein, aimed to encourage international cultural exchange and understanding through mutual information, knowledge about key positions, and the elucidation of public opinion in Europe in order to prevent a further increase of tensions between the continent's main geopolitical alliances. ${ }^{110}$ Historian of science Rüdiger vom Bruch has commented that in the first of the two special issues on British-German relations, Arthur James Balfour, the former British Prime Minister (1902-1905), Conservative Party Leader, and Leader of the Opposition, was the only contributor who was openly sceptical about mutual rapprochement because he argued that depending on the underlying motives of the high seas fleet, German armament and world politics were perceived as potenially threatening to the United Kingdom. Yet, in response to these two special issues, most press reports played down the possibility of armed conflict and instead emphasised the achievements of English-German understanding. ${ }^{111}$ Voigt's speech in the Royal Society was therefore a balancing act between an insistence on German unity and a wider public interest to appease.

\section{Geikie's reactions}

During the editing process of the event proceedings, Geikie avoided overemphasizing the bronze tablet by literally putting the German universities in their place. In an exchange with Horace Hart, Printer to the University of Oxford and Controller of the University Press, Geikie wrote: 
The Tablet cannot be made the frontpiece.

That would be giving it too much prominence.

I would much prefer that it should appear,

as I indicated, on p46 which is its proper place.

It should be slightly reduced so as to go easily into the page. ${ }^{112}$

In the final publication, the reduced image of the bronze tablet, together with a short description, was presented in the alphabetical order of countries on page 48. Yet, this entry on Germany, the only one in the proceedings with an image rather than a typed address, documents that the German present was appreciated so much by its receivers that the bronze tablet was displayed in the entrance hall of the Royal Society's apartments in Burlington House. ${ }^{113}$ This was a symbolic place in itself because Geikie, a geologist who published on Latin literature, ${ }^{114}$ might have known that from Emperor Augustus' times onwards, the corona civica crowned the entrance to the Roman emperor's palace. ${ }^{115}$

On 30 November 1912, Geikie awarded the Royal Society's most prestigious honour, the Copley medal, to the world-renowned German mathematician Felix Klein from the University of Göttingen. This was a remarkable move because there had been a conspicuous absence of scientists from the German Empire among the Copley medallists since the Swiss anatomist Albert von Kölliker from the University of Würzburg had received this honour in 1897 . Honouring a theoretician, rather than an experimentalist whose research might have supported the omnipresent 
arms race, can certainly be interpreted as a statement about the type of German research Geikie and fellow British scientists valued most. ${ }^{116}$ Despite its geopolitical message of German unity, the bronze tablet contributed to further scientific recognition and expression of personal appreciation a year later, because Geikie was still President of the Royal Society when Voigt was elected as a foreign member in June 1913.117

In his autobiography of 1924 , published six years after the end of WWI, at a time when German scientists and scholars were still banned from attending international scientific conferences as a consequence of their propagandistic support of the war, ${ }^{118}$ Geikie expressed how proud he was that every European country had sent delegates to the Society's anniversary celebrations and that the largest delegation had arrived from the United States. He emphasised that universities and learned societies from the British Isles, the dominions, and dependencies were well represented at the event, before mentioning explicitly that the 'German universities which sent delegates, instead of each presenting a separate address, with great sense and good taste combined to offer a large bronze tablet with a Latin inscription recording the congratulations of the German universities'. ${ }^{119}$ As a scientist versed in Latin, Geikie thus fondly remembered the stylish bronze tablet and its ancient connotations when recalling the event, even attributing 'good taste' to the Germans. On the complex nature of British-German relations, Geikie wrote with hindsight: 
So far from there being among us at that time any widespread conviction that Germany was bent on war[,] various active agencies were at work to promote cordial relations with that country. [...] At the same time there were far-seeing prophets who, pointing to the gigantic growth of the German army and navy, warned us to prepare and be on our guard. ${ }^{120}$

The actions, reactions, and perceptions of one of the most powerful British scientists at the time therefore confirm that on the eve of WWI, the international scientific community was affected by complicated, ambivalent tensions. Conflicting developments resulted especially from the celebration of scientific internationalism, national cultural achievements, institutional grandness, and individual scientific accomplishments in the contrasting contexts of professional collaborations, personal networks, and scientific friendships versus national rivalry, confrontational politics, and imperial interests. ${ }^{121}$ Whom Geikie's recollections did not mention were the agitators and warmongers on the British side, as exemplified by St Andrews' Chancellor Lord Balfour of Burleigh, who had politicised the 1911 scientific jubilee in St Andrews through geographical imaginations about the expansion of the British Empire. 


\section{The proliferation of German unity and bronze tablets}

The demonstration of unity among German universities as performed in the Royal Society was a considerable achievement, especially because similar attempts to coordinate the German universities had failed. As Trude Maurer has written, the Prussian historian Friedrich Meinecke, a professor at the University of Freiburg in the years before WWI, who worked on the relationship between cosmopolitanism and nation states, and was known for national liberal and anti-Semitic views, had proposed twice that German universities should cooperate for the commemoration of the centenary of the War of Liberation in 1913. In 1910, Meinecke had suggested that the German universities should work together with other institutions to mark this event, and in 1912, he proposed that individual university jubilees 'should work like one big unified ceremony of German professors and students'. ${ }^{122}$ Yet, in contrast to Voigt's successful approach in 1912, these ideas were not taken forward by Prussian and imperial authorities because, as Maurer has argued, the 'varying design of local celebrations proved that there was no uniform guideline even for Prussian universities'. ${ }^{123}$

Socio-practical legacies

In the context that previous attempts to coordinate the activities of German universities remained unsuccessful, we argue that the materialisation of German academic unity in the Royal Society had direct socio-practical consequences for the creation of a working national system 
of German universities. According to Bernhard vom Brocke and Peter Krüger, institutionalised cooperation among German universities began in 1898 when Friedrich Althoff, Ministerial Director in the Prussian Ministry of Culture, organised a first university conference for representatives of German federated governments in Eisenach, which continued almost annually until $1933 .{ }^{124}$ Since many universities were in opposition to this official annual event and the resulting increase in centralised governance, the 21 German universities organised their own, non-official all-German Rectors' Conferences for academic university leaders, their predecessors, and successors in 1903, with a pre-assembly in Eisenach and a full assembly in Leipzig. ${ }^{125}$ Two further non-official all-German Rectors' Conferences, organised by the universities themselves, were held in 1907 (Marburg) and 1913 (Halle). Yet, only in Halle, eight months after the successful self-coordination of all German universities for their joint address and present in the Royal Society, it was decided to institutionalise these conferences as annual events. ${ }^{126}$

Our study suggests that the twofold proposal in May 1912 by von Lilienthal, the Rektor of the University of Heidelberg, to establish either an all-German Rectors' Conference or a special commission to coordinate future collaborations between all German universities paved the way for the annual non-official all-German Rectors' Conferences from 1913 onwards. This annual conference series, which has continued under different names up until today (known since 1990 as the Hochschulrektorenkonferenz, or in short HRK), can therefore be regarded 
as a direct outcome of the initiative to provide a joint present from Prussian and non-Prussian universities to the Royal Society in July 1912. ${ }^{127}$ At the non-official all-German Rectors' Conference in Halle in 1913, two further decisions of interest were made. On the one hand, Lamprecht's suggestion to hold regular Pan-Germanic or international Rectors' Conferences was disregarded because the former Rektor was not seen as eligible to provide an agenda point for discussion without his university senate's agreement. On the other hand, the 21 German universities-represented in Halle by at least one delegate-decided to present a second brazen tabula gratulatoria in Latin on behalf of all German universities to the University of Groningen at its tercentenary in July 1914 , under the leadership of the Rektors of Bonn and Strasbourg. ${ }^{128}$

\section{Material-semiotic impacts}

The tercentenary celebrations at the University of Groningen took place from 29 June to 1 July 1914 and thus began one day after the shooting of the Archduke and Archduchess of Austria and ended one month before the start of WWI. ${ }^{129}$ Adding to these portentous signs of the times, Italian institutions were not participating in the presentation of addresses (Figure 1). With hindsight, this absence anticipated Italy staying neutral at the start of the war and not only leaving the Triple Alliance but entering the war on the side of the Triple Entente in 1915. Yet, local elections taking place across the country, in cities such as Bologna on 28 June 1914, certainly hindered Italian participation. ${ }^{130}$ 
The invitations for the tercentenary had been drafted in Latin but the three main speeches on Monday, 29 June by professors Isaac van Dijk (Groningen) and Émile Durkheim (Paris), as well as student M. J. Bos, were delivered in French. ${ }^{131}$ The predominantly western and central European event was taken most seriously by the universities from the German Empire, with all but the University of Greifswald represented (Figure 1; Table 1d). Yet, the equal number of 20 British universities from the homeland (12) and the empire (8)-formally joined since 1913 by the Universities Bureau of the British Empire in London, the world's oldest transnational university network-demonstrated their adoption of the global humanistic habitus evoked at the end of Voigt's Royal Society speech by presenting their jubilee addresses in Latin-from London via Toronto and Adelaide to Bombay. The British universities also seemed to have responded to Voigt's comments about another academic invisible college stretching across the world than initiated by the Royal Society, when editing the first English-language Yearbook of the Universities of the Empire in 1914. This compendium appears to have been modelled on the German-language yearbook of the universities of the world that had appeared in print annually since 1891-1892 and was named after the Roman goddess Minerva, the equivalent to the Greek goddess Athena. ${ }^{132}$

The second tabula gratulatoria casted in bronze on behalf of all German universities in honour of the University of Groningen had been created by artist Otto Hupp in Munich. Showing a similar size as the Royal Society's bronze tablet but designed in landscape format with an 
ornamented picture-like frame, this tabula gratulatoria displayed one laurel wreath for each of the three centuries of Groningen's university history above six lines of Latin text conveying congratulations and admiration. Initially stuck at customs despite having been in transit from Munich for seven days, the bronze tablet for Groningen arrived-to the great embarrassment of the speaker for the German universities, the historian Alois Schulte, Rektor of the University of Bonn-one day after the presentation of addresses. ${ }^{133}$ Yet, the German present could still be handed over in the morning of the final day of ceremony, when it received undivided attention and was well received. ${ }^{134}$ Compared to the Royal Society's bronze tablet, whose destiny has been unknown since it was on display in the entrance hall of the Society's quarters in Burlington House, ${ }^{135}$ the bronze tablet for the University of Groningen still serves as a memento for the demonstration of German academic unity overseas. This is because Hupp's bronze cast was, as requested by the German universities, walled up in a prominent place on the downstairs corridor of Groningen's stylish Academy Building (Figure 3). ${ }^{136}$

[Please insert Figure 3 about here]

Our analysis has thus demonstrated that the two bronze tablets from the German universities for the Royal Society and the University of Groningen shared three main purposes: they epitomised more or less durable mementos of scientific internationalism; they communicated a 
political message about a new era of nationalism; and they embodied a strategy of foreign cultural policy. Yet, their multiple and partly contradictory messages that straddled the realms of science and politics by expressing academic recognition, conveying the idea of united strength as deterrence, and reinforcing cordial relationships also served slightly different goals in their varying presentation contexts. The Royal Society tablet may have aimed at preventing a war with the United Kingdom, whereas the Groningen tablet tried to encourage an alliance with the neutral nation of the Netherlands. ${ }^{137}$

The bronze tablets for the Royal Society and the University of Groningen were followed by a third bronze plaque of interest, casted by the creator of the Royal Society's bronze tablet, Rudolf Bosselt, on the occasion of the foundation of the civic University of Frankfurt on 18 October 1914. ${ }^{138}$ This bronze plaque took up the image of the Pallas Athena, the Greek goddess of wisdom and warfare, which is prominently displayed on one of the oldest international scientific awards, the Copley medal of the Royal Society, first produced in $1742 .{ }^{139}$ In contrast to the Copley medal Athena, who is sitting sparsely armed on a pedestal, reaching out with her right arm to present a wreath of laurels, ${ }^{140}$ the bronze plaque designed after the start of WWI for the new University of Frankfurt shows an Athena in arms. Depicted is the meaningful emblem of the upper body of a left facing Athena, equipped with aegis, helmet, lance, and owl, above a dedication to the university and its teachers by the new university's Kuratorium, or Board of Trustees (Figure 4). 
[Please insert Figure 4 about here]

The bronze plaque for the University of Frankfurt had been suggested by Frankfurt's major Franz Adickes to his fellow trustees. ${ }^{141}$ Adickes had played a key role in establishing the University of Frankfurt together with the institution's founding Director and Professor of Experimental Physics, Richard Wachsmuth. He also composed the war prose on the back of the plaque, where four and five lines of text, respectively, were interspersed between three small stars to commemorate the university's act of creation, 'as a fortress of the intellect', 'in troops and arms' by an 'iron generation' for 'Germany's honour - in research and teaching - faithfully truthful and just'. ${ }^{142}$ Clearly shaped by the start of WWI, which had seen the German Empire and Austria-Hungary fighting against the Triple Entente of the UK, France, and Russia since August 1914, Frankfurt's bronze plaque needs to be situated within an uncompromising identification of most German academics with the German war effort.

Imaginative-discursive effects

By October 1914, the German academic unity expressed in the Royal Society had been extended to a self-confessed union between the German universities, the German army, and the German nation. After several calls for and against the war in British and German newspapers, a declaration of war solidarity about 'Britain's destiny and duty', signed by 53 British 
writers, was published by The Times on 18 September 1914. This declaration separated British opposition against Prussian militarism from admiration for German culture. ${ }^{143}$ In response, German newspapers published on 4 October 1914 the highly controversial and distinctively racist manifesto 'An die Kulturwelt' ('To the Civilised World!'), which was signed by 93 leading German figures, translated into 14 languages, and aimed to justify German war action by arguing that fighting against the German Empire's militarism would mean fighting against German culture. Since this appeal denied war atrocities in Belgium, and perhaps because it was racist, several signatories later regretted signing the document, with some signees claiming that they signed an appeal against foreign propaganda that they had not read. ${ }^{144}$

As a next step in this medial science war, over 3,000 German academics (c. 80\%) from 53 universities and colleges signed the 'Declaration by the university teachers of the German Empire' from 16 October 1914 (also dated 23 October 1914). The signees included Franz Adickes' brother Erich Adickes, who was a Professor of Philosophy at the University of Tübingen, and all other German actors mentioned in this essay, from Voigt in Göttingen and Veit in Halle, via von Duhn, von Lilienthal, and long-term Royal Society Fellow Quincke in Heidelberg, to Lamprecht in Leipzig and Wachsmuth in Frankfurt. In this short press declaration, German academics responded to what they perceived as enemy propaganda-with 'England at the forefront'-by positioning themselves firmly on the side of what was widely addressed as 'Prussian 
militarism'. ${ }^{145}$ This declaration emphasised the greatest possible degree of German unity across Prussia and 'all regions of the German Empire'. Yet, being issued within three months after the German Empire and the United Kingdom had entered WWI, this declaration also justified a war 'in the fight for Germany's freedom', anticipating a victory based on 'the masculinity, loyalty, courage of sacrifice of the harmonious free German people' for the salvation of 'the whole culture of Europe'. ${ }^{146}$

In response, the September declaration from The Times was printed in the New York Times (18 October) and a 'Reply to the German Professors', signed by 117 British academics, was published in The Daily Telegraph (21 October). ${ }^{147}$ In his President's address at the Royal Society's anniversary meeting on 30 November 1914, Geikie's successor of only two years, the chemist Sir William Crookes, cited a German newspaper when calling the German professors' manifesto 'a grave symptom of national insanity', before predicting that 'their reliance on brute force is doomed to end in failure ${ }^{\prime}{ }^{148}$ He pointed out that the 'dignified reply of the English scholars'-in The Daily Telegraph-drew on facts and referred explicitly to the unity of universities in Germany's longterm academic rival France, when stating that ' $[t]$ he united universities of France have addressed to the universities of the neutral nations a noble and imposing document in which the claims of Germany are answered in a manner beyond all question'. ${ }^{149}$

In this wider context, it is likely that the joint present of the German universities to the Royal Society was removed from the walls of 
Burlington House either in the time leading up to WWI or after war had broken out. Such action would have been a most obvious response to the war hostilities and might have been linked to the incident that the first Nobel Laureate in Physics, Wilhelm Conrad Röntgen from the University of Munich, had given his 1896 Rumford medal of the Royal Society away to be melted in support of the war, a decision that was mentioned by Sir William Crookes in his President's address at the Royal Society's anniversary meeting on 30 November 1914 and that Röntgen later deplored. ${ }^{150}$ The start of WWI would then have encouraged the bronze plaque designed by Bosselt for the new University of Frankfurt; yet, this time, the chosen iconography conveyed a much more straightforward geopolitical message when displaying an Athena equipped with weapons facing westwards, towards France and the United Kingdom, by then the German Empire's WWI enemies despite such a highly venerated scientific institution as the Royal Society.

\section{Conclusions}

In this essay, we have identified the origins of a new era in science and politics characterised by national coordination among universities, an escalation of scientific nationalism, and global wars. We argue that the cultural geopolitics of international scientific jubilees provided an important catalyst for national perceptions of higher education to be reinforced in the years before WWI. The grouping of national delegations at such jubilees, together with struggles over language, cultural and academic leadership, and national political interests, raised self- 
awareness about national academic identities at the expense of cosmopolitan ideals associated with scientific internationalism. Our reconstruction of a major change in academic self-representation at scientific jubilees, namely from delivering individual congratulatory addresses by representatives of up to 21 German universities to presenting one joint address and present to the Royal Society on the occasion of its 250th anniversary as a chartered institution, has revealed that the formation of unity among German universities in the years before WWI explains the start of a new era.

Underlining the great extent to which geopolitical struggles were an integral part of early twentieth-century international academic relations, our analysis has contributed new insights to interdisciplinary debates about the development of scientific nationalism in the German Empire. ${ }^{151}$ We have shown that scientific nationalism was encouraged in early September 1911 by anti-German sentiments and provocative statements about British imperial expansion at the university jubilees in Kristiania and St Andrews. Yet, the subsequent demonstration of unity among all Prussian and non-Prussian German universities through the joint presentation of an inscribed bronze tablet to the Royal Society in mid-July 1912 was not only a response to these jubilee experiences but also to the formation of unity among British universities, widely publicised in the second November 1911 issue of Nature with the announcement of the Congress of the Universities of the Empire to be held in London in early July 1912 . We therefore argue that the scientific jubilees in Kristiania, St Andrews, and London had become politicised spaces in which the resource ensembles of science and politics amalgamated when the announcements 
of an expanding and academically unifying British Empire were countered through the demonstration of German unity in bronze.

This striking episode about the formation of unity among German universities is of particular significance to the histories and geographies of science and the university for three reasons. First, other proposals for coordinated action among universities within the German Empire were declined at the time. Second, profound socio-practical, material-semiotic, and imaginative-discursive outcomes resulted from the demonstration of German academic unity overseas. These outcomes ranged from the institutionalisation of annual non-official all-German Rectors' Conferences in 1913-known as Hochschulrektorenkonferenz (HRK) since 1990-via two further bronze casts in 1914, aiming to reinforce the geopolitical ideas of German unity, prowess, and national pride not only overseas-at the tercentenary in Groningen-but also at home-in the new University of Frankfurt, to the imaginative-discursive identification of German academics with the German army and the whole German nation in press declarations after the start of WWI. Third, our observation that the formation of unity among the universities of the German Empire emerged in rivalry with the formation of unity among the universities of the British Empire underlines the significance of this essay's finding that in the wider political context of the Anglo-German naval race and the German Empire's desire to become a global imperial power, the escalation of German scientific nationalism in 1914 was to a larger degree provoked through the repeated politicisation of international encounters, interactions, and discourses at Western European scientific jubilees than previously known. 
Consequently, we propose to add the years 1912 to 1914 to Ash's outline of major changes in twentieth-century German-language European landscapes of science and politics around 1933, 1945, and $1989^{152}$ because this earlier period saw a substantial reconfiguration of material, practical, and imaginative resource ensembles at home and abroad. In the context of growing tensions between scientific internationalism and political nationalism on the eve of WWI, this new era was epitomized by the manifestation of a national identity among all German universities in the Royal Society in July 1912 and the subsequent institutionalisation of their mutual coordination, which both created a working national system of universities. The pivotal significance of the related changes in selfrepresentation and academic praxis is evident when considering that despite the important role of students and academics for shaping German nationalism during the nineteenth century, it took more than four decades after the constitution of the German Empire (1871) until all 21 Prussian and non-Prussian universities demonstrated their unity overseas. Knowing about the events that led to this expression of scientific nationalism and the ultimate alignment of German science and politics, does not necessarily make it more comprehensible that such a large number of world renowned academics-including Protestants, Catholics, and Jews but only men-displayed an uncompromising loyalty to Emperor Wilhelm II's war strategy in the early stages of WWI, yet it helps to understand the onset of a new era in global science and politics and the victorious Allies' post-war boycott of German science and language in international conferences, institutions, and projects that lasted for eight years. ${ }^{153}$ 


\section{Acknowledgements}

We are grateful to the Fritz Thyssen Foundation for funding the project that enabled this research (Grant 10.16.2.014GE). Principle Investigator Heike Jöns is especially grateful to Dr Ingo Runde and Ms Sabrina Zinke for their generous support of her archival research in Heidelberg, during which she found the discussion and image of the bronze tablet for the Royal Society, and to Ms Katherine Marshall (London) and Dr Arjen Dijkstra (Groningen) for their archival research support on the Royal Society and Groningen events. We also like to thank the Heidelberg University Archives, the Göttingen University Archives, the Royal Society Archives, and the University Museum Groningen for permission to reproduce the material cited in this essay; and the editor and anonymous reviewers for their constructive feedback. 


\section{Figures and tables}

Figure 1

Overseas institutions represented by delegates at scientific jubilees

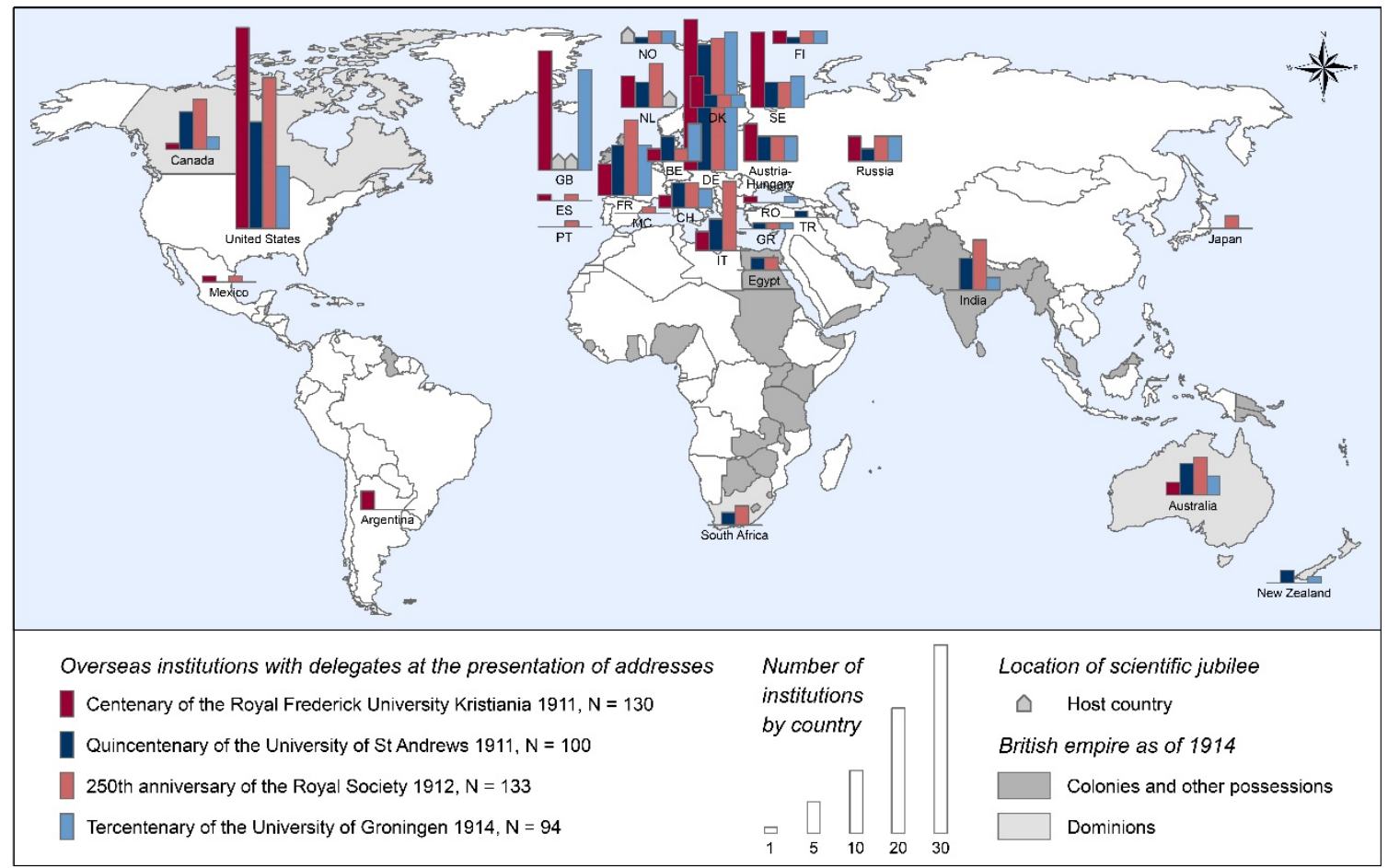

Sources: Fredrik Barbe Wallem (ed.), Det kongelige Frederiks Universitets hundreaarsjubilæum 1911 (A.W. Brøggers boktrykkeri a/s, Kristiania, 1913), at pp. 15-21; The quincentenary of the University of St Andrews (The University Press, Aberdeen, 1912), at pp. 10-20, 22; Royal Society (ed.), The celebration of the two hundred and fiftieth anniversary of the Royal Society of London, 15-19 July 1912 (Royal Society, London, 1913), at pp. 13-18; Academische Senaat (ed.), Academia groningana, 29 Juni1 Juli 1914: verslag van de herdenking van het derde eeuwfeest der Universiteit te Groningen (J. B. Wolters, Groningen, 1916), at pp. 19-27. 
Figure 2

Documentation of the bronze tablet by Rudolf Bosselt presented on behalf of the German universities to the Royal Society on 16 July 1912

\section{GERMANY}

The Universities of Germany, instead of each preparing an Address, combined their felicitations upon a large bronze 'Tablet which, at the Reception of the Royal Society, was presented in their name by Professor Dr. Woldemar Voigt, Rector of the University of Göttingen. Delegates were at the same time present from the Universities of Berlin, Bonn, Breslau, Erlangen, Freiburg-im-Breisgau, Giessen, Göttingen, Greifswald, Halle, Heidelberg, Königsberg, Leipzig, Marburg, Munich, Münster, Rostock, Strassburg, and Tübingen. The Tablet, which is shown in the accompanying illustration, now hangs on the wall of the Entrance-hall of the Society's apartments in Burlington House.

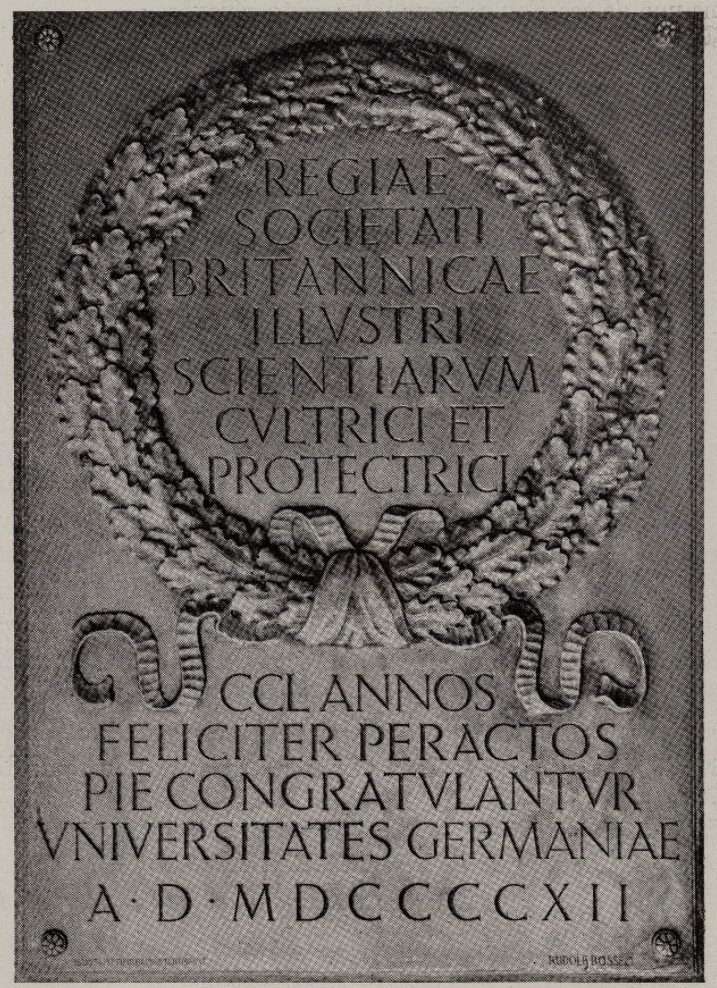

Source: Royal Society (ed.), The celebration of the two hundred and

fiftieth anniversary of the Royal Society of London, 15-19 July 1912

(Royal Society, London, 1913), at p. 48. 
Figure 3

Bronze tablet by Otto Hupp presented on behalf of the German universities to the University of Groningen on 1 July 1914

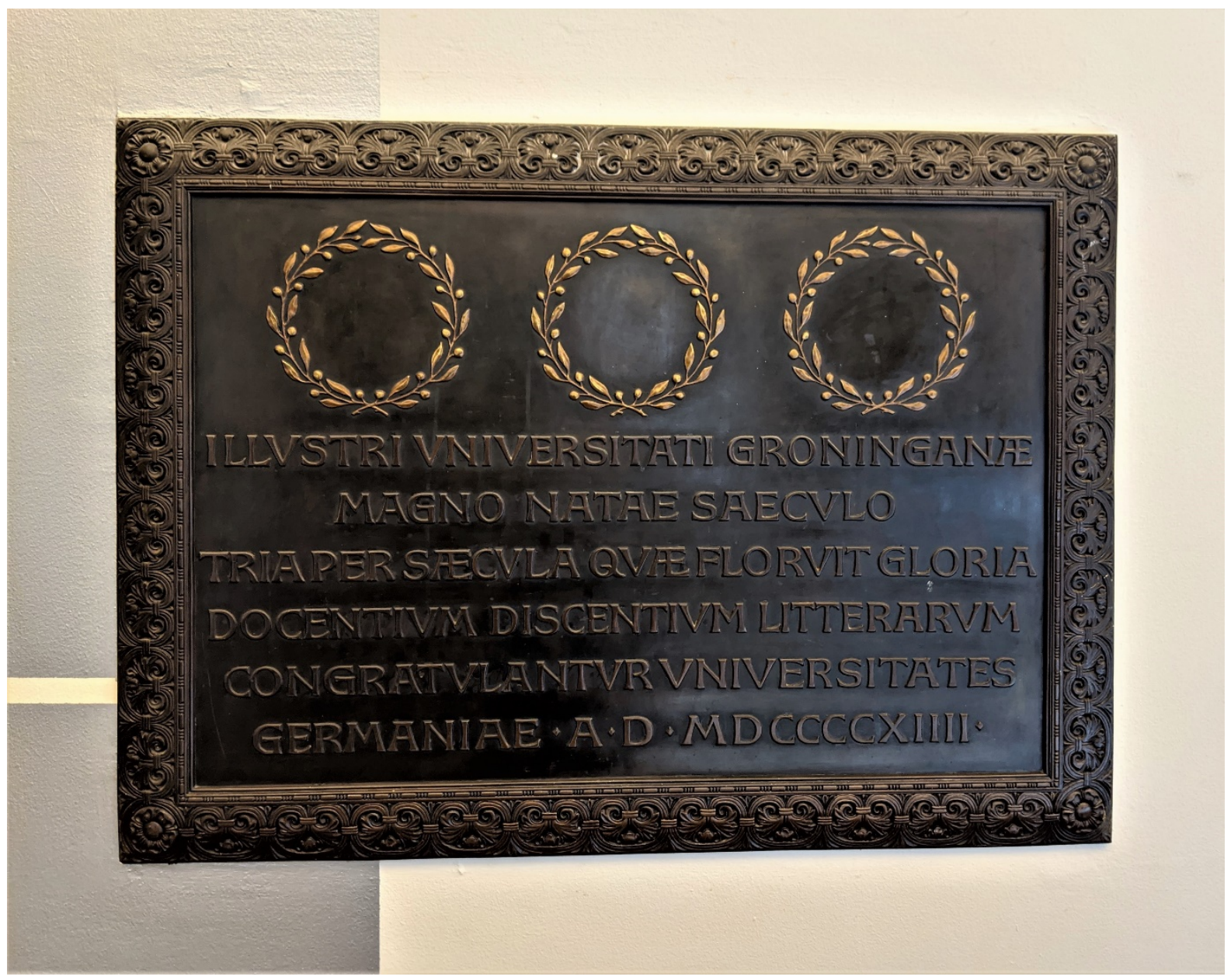

Source: Photo by Dr Arjen Dijkstra, Head of the University Museum Groningen, taken in the Academy Building of the University of Groningen. 
Figure 4

Bronze plaque by Rudolf Bosselt on the occasion of the foundation of the University of Frankfurt on 18 October 1914

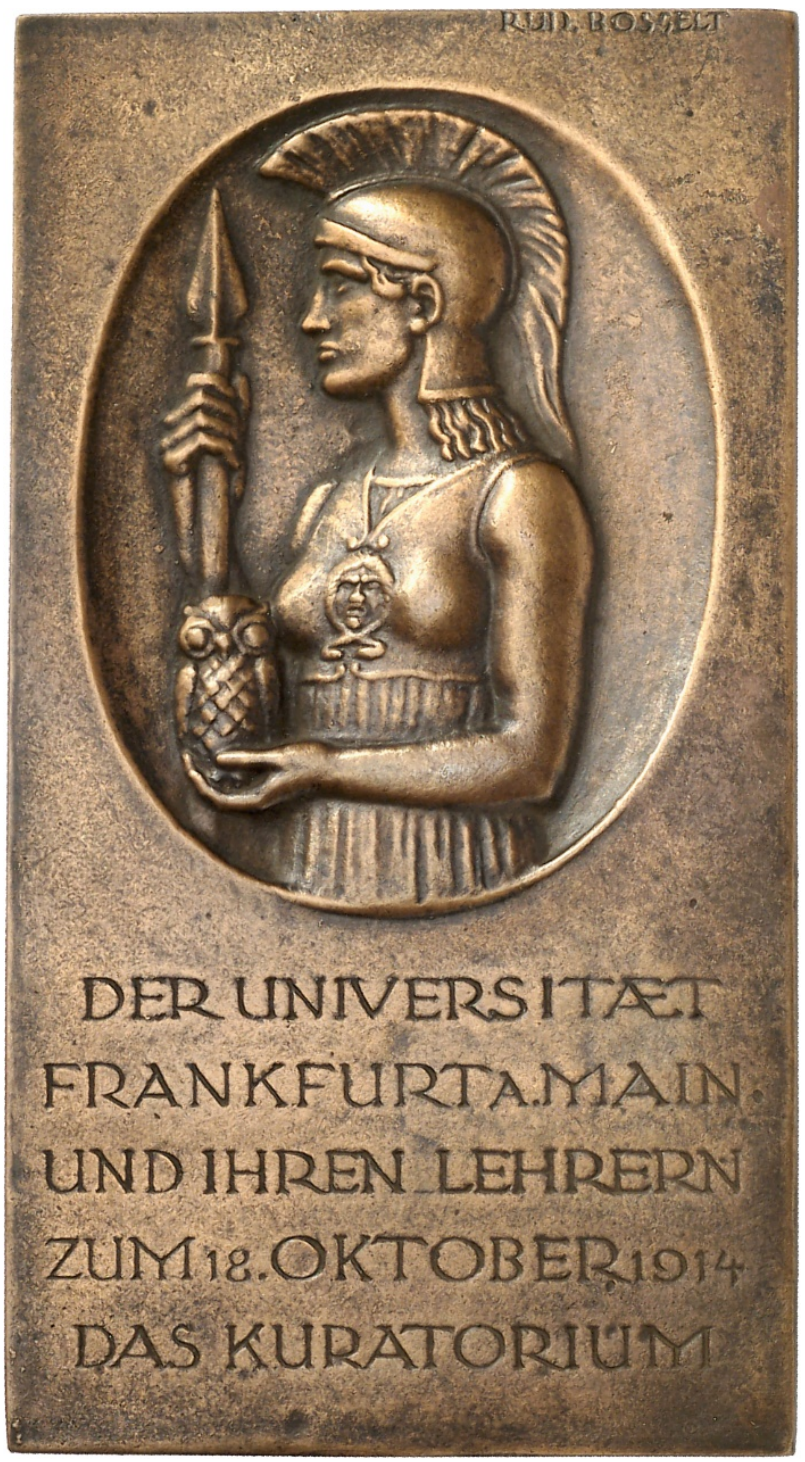

Source: Münzkabinett, Staatliche Museen zu Berlin, 18234647; photo by Lutz-Jürgen Lübke (Lübke and Wiedemann);

https://ikmk.smb.museum/object?id=18234647 (accessed 4 December 2020). 
Table 1 Geographical distribution of overseas institutions represented by delegates at scientific jubilees

(a) The centenary of the Royal Frederick University, 1911

\begin{tabular}{|c|c|c|c|c|c|c|}
\hline \multirow[t]{2}{*}{ Region } & \multicolumn{4}{|c|}{$\begin{array}{l}\text { Overseas institutions } \\
\text { Learned societies, } \\
\text { scientific \& other } \\
\text { institutions }\end{array}$} & \multicolumn{2}{|c|}{ Total } \\
\hline & $\mathrm{N}$ & $\%$ & $\mathrm{~N}$ & $\%$ & $\mathrm{~N}$ & $\%$ \\
\hline Europe \& Russia & 60 & 65 & 31 & 82 & 91 & 70 \\
\hline Germany & 18 & 20 & 6 & 16 & 24 & 19 \\
\hline France & 4 & 4 & 1 & 3 & 5 & 4 \\
\hline UK & 11 & 12 & 8 & 21 & 19 & 15 \\
\hline North America & 27 & 29 & 7 & 18 & 34 & 26 \\
\hline United States & 25 & 27 & 7 & 18 & 32 & 25 \\
\hline South America & 3 & 3 & 0 & 0 & 3 & 2 \\
\hline Asia Pacific & 2 & 2 & 0 & 0 & 2 & 2 \\
\hline Africa & 0 & 0 & 0 & 0 & 0 & 0 \\
\hline Total & 92 & 100 & 38 & 100 & 130 & 100 \\
\hline
\end{tabular}

Source: $\quad$ Fredrik Barbe Wallem (ed.), Det kongelige Frederiks Universitets hundreaarsjubilæum 1911 (A.W. Brøggers boktrykkeri a/s, Kristiania, 1913), at pp. 15-21.

(b) The quincentenary of the University of St Andrews, 1911

\begin{tabular}{crrrrrr}
\hline \multirow{2}{*}{ Region } & \multicolumn{5}{c}{$\begin{array}{c}\text { Overseas institutions } \\
\text { Learned societies, } \\
\text { scientific \& other } \\
\text { institutions }\end{array}$} & Total \\
\cline { 2 - 8 } & Universities & $\mathrm{N}$ & $\%$ & $\mathrm{~N}$ & $\%$ \\
\cline { 2 - 7 } Europe \& Russia & 50 & 59 & 11 & 73 & 61 & 61 \\
Germany & 15 & 18 & 5 & 33 & 20 & 20 \\
France & 7 & 8 & 1 & 7 & 8 & 8 \\
Sorth America & 19 & 22 & 4 & 27 & 23 & 23 \\
United States & 14 & 17 & 3 & 20 & 17 & 17 \\
Asia Pacific & 0 & 0 & 0 & 0 & 0 & 0 \\
Africa & 12 & 14 & 0 & 0 & 12 & 12 \\
& 4 & 5 & 0 & 0 & 4 & 4 \\
\hline
\end{tabular}

Source: The quincentenary of the University of St Andrews

(The University Press, Aberdeen, 1912), at pp. 10-20, 22. 
(c) The $250^{\text {th }}$ anniversary of the Royal Society in London, 1912

\begin{tabular}{|c|c|c|c|c|c|c|}
\hline \multirow[t]{2}{*}{ Region } & \multicolumn{4}{|c|}{$\begin{array}{l}\text { Overseas institutions } \\
\text { Learned societies, } \\
\text { scientific \& other } \\
\text { institutions }\end{array}$} & \multicolumn{2}{|c|}{ Total } \\
\hline & $\mathrm{N}$ & $\%$ & $\mathrm{~N}$ & $\%$ & $\mathrm{~N}$ & $\%$ \\
\hline Europe \& Russia & 49 & 58 & 30 & 63 & 79 & 59 \\
\hline Germany & 18 & 21 & 3 & 6 & 21 & 16 \\
\hline France & 6 & 7 & 6 & 13 & 12 & 9 \\
\hline North America & 21 & 25 & 12 & 25 & 33 & 25 \\
\hline United States & 14 & 17 & 10 & 21 & 24 & 18 \\
\hline South America & 0 & 0 & 0 & 0 & 0 & 0 \\
\hline Asia Pacific & 11 & 13 & 5 & 10 & 16 & 12 \\
\hline Africa & 4 & 5 & 1 & 2 & 5 & 4 \\
\hline Total & 85 & 100 & 48 & 100 & 133 & 100 \\
\hline
\end{tabular}

Source: Royal Society (ed.), The celebration of the two hundred and fiftieth anniversary of the Royal Society of London, 15-19 July 1912 (Royal Society, London, 1913), at pp. 13-18.

(d) The tercentenary of the University of Groningen, 1914

\begin{tabular}{|c|c|c|c|c|c|c|}
\hline \multirow[t]{2}{*}{ Region } & \multicolumn{2}{|c|}{ Universities } & \multicolumn{2}{|c|}{$\begin{array}{l}\text { Learned societies, } \\
\text { scientific \& other } \\
\text { institutions }\end{array}$} & \multicolumn{2}{|c|}{ Total } \\
\hline & $\mathrm{N}$ & $\%$ & $\mathrm{~N}$ & $\%$ & $\mathrm{~N}$ & $\%$ \\
\hline Europe \& Russia & 62 & 80 & 14 & 88 & 76 & 81 \\
\hline Germany & 20 & 26 & 2 & 13 & 22 & 23 \\
\hline France & 7 & 9 & 1 & 6 & 8 & 9 \\
\hline UK & 12 & 15 & 4 & 25 & 16 & 17 \\
\hline North America & 10 & 13 & 2 & 13 & 12 & 13 \\
\hline United States & 8 & 10 & 2 & 13 & 10 & 11 \\
\hline South America & 0 & 0 & 0 & 0 & 0 & 0 \\
\hline Asia Pacific & 6 & 8 & 0 & 0 & 6 & 6 \\
\hline Africa & 0 & 0 & 0 & 0 & 0 & 0 \\
\hline Total & 78 & 100 & 16 & 100 & 94 & 100 \\
\hline
\end{tabular}

Source: Academische Senaat (ed.), Academia groningana, 29 Juni-1 Juli 1914: verslag van de herdenking van het derde eeuwfeest der Universiteit te Groningen (J. B. Wolters, Groningen, 1916), at pp. 19-27. 


\section{Notes}

${ }^{1}$ Elisabeth Crawford, Nationalism and internationalism in science, 1880-1939 (Cambridge University Press, Cambridge, 1992), at pp. 28-46; Elisabeth Crawford, Terry Shinn, and Sverker Sörlin, 'The nationalization and denationalization of the sciences: an introductory essay', in Denationalizing science: the contexts of international scientific practice (eds Elisabeth Crawford, Terry Shinn, and Sverker Sörlin), pp. 1-42 (Springer, Dordrecht, 1993), at pp. 11-21; Martin H. Geyer and Johannes Paulmann, 'Introduction: the mechanics of internationalism', in The mechanics of internationalism: culture, society, and politics from the 1840s to the First World War (eds Martin H. Geyer and Johannes Paulmann), pp. 1-25 (Oxford University Press, Oxford, 2001), at pp. 5-7; Pieter Dhondt, 'Introduction: nineteenth-century university jubilees as the driving force of increasing Nordic cooperation', in National, Nordic or European? Nineteenth-century university jubilees and Nordic cooperation (ed. Pieter Dhondt), pp. 1-9 (Brill, Leiden, 2011); Mitchell G. Ash and Jan Surman, 'The nationalization of scientific knowledge in nineteenth-century Europe: an introduction', in The nationalization of scientific knowledge in the Habsburg Empire, 1848-1918 (eds Mitchell G. Ash and Jan Surman, 2012), pp. 1-29 (Palgrave, New York); Robert Fox, Science without frontiers: cosmopolitanism and national interests in the world of learning, 1870-1940 (Oregon State University Press, Corvallis, 2016); Emily J. Levine, 'Baltimore teaches, Göttingen learns: cooperation, competition, and the research university', The American Historical Review, 121, pp. 780-823 (2016).

${ }^{2}$ Crawford, op. cit. (note 1), at p. 36. On the international initiatives, see Bernhard vom Brocke, 'Der deutsch-amerikanische Professorenaustausch: preußische Wissenschaftspolitik, internationale Wissenschaftsbeziehungen und die Anfänge einer deutschen auswärtigen Kulturpolitik vor dem Ersten Weltkrieg', Zeitschrift für Kulturaustausch, 31, pp. 128-182 (1981), at pp. 140-143; Elisabeth Crawford, The beginnings of the Nobel institution: the science prizes, 1901-1915 (Cambridge University 
Press, Cambridge, 1984); Jagdish Mehra, The Solvay conferences on physics: aspects of the development of physics since 1911 (Dordrecht, D. Reidel, 1975).

${ }^{3}$ The idea of the nation as an imagined political community has been developed by Benedict Anderson, Imagined communities: reflections on the origins and spread of nationalism. Revised edition (Verso, London, 1991), at pp. 5-8.

${ }^{4}$ Charles E. McClelland, State, society, and university in Germany, 1700-1914 (Cambridge University Press, Cambridge, 1980), at pp. 9, 217-218; Woodruff D. Smith, Politics and the sciences of culture in Germany, 1840-1920 (Oxford University Press, Oxford, 1991), at pp. 94-97.

5 Jörn Echterkamp, Der Aufstieg des deutschen Nationalismus (1770-1840) (Campus Verlag, Frankfurt, 1998), at p. 43; Michael Heffernan, The meaning of Europe: geography and geopolitics (Arnold, London, 1998), at pp. 23-45.

${ }^{6}$ Echterkamp, op. cit. (note 5), at p. 45.

${ }^{7}$ Smith, op. cit. (note 4), at p. 97; Walter Rüegg, 'Themes', in A history of the university in Europe: volume III: universities in the nineteenth and early twentieth centuries (1800-1945) (ed. Walter Rüegg), pp. 3-31 (Cambridge University Press, Cambridge, 2004), at pp. 22-24. See also Peter Hoerdes, Krieg der Philosophen: die deutsche und die britische Philosophie im Ersten Weltkrieg (Ferdinand Schöningh, Paderborn, 2004). ${ }^{8}$ Konrad H. Jarausch, Students, society and politics in imperial Germany: the rise of academic illiberalism (Princeton University Press, Princeton, 1982), at pp. 6-8, 11-13, 399-416; Smith, op. cit. (note 4), at pp. 97-99.

9 Jarausch, op. cit. (note 8), at pp. 388-389; See also Lieve Gevers and Louis Vos, 'Student movements', in A history of the university in Europe: volume III: universities in the nineteenth and early twentieth centuries (1800-1945) (ed. Walter Rüegg), pp. 269361 (Cambridge University Press, Cambridge, 2004), at pp. 328-330.

${ }^{10}$ Rainer Christoph Schwinges (ed.), Humboldt international: der Export des deutschen Universitätsmodells im 19. und 20. Jahrhundert (Schwabe Verlag, Basel, 2001); Edward Shils and John Roberts, 'The diffusion of European models outside Europe', in A history 
of the university in Europe: volume III: universities in the nineteenth and early twentieth centuries (1800-1945) (ed. Walter Rüegg), pp. 163-230 (Cambridge University Press, Cambridge, 2004). See also William Clark, Academic charisma and the origins of the research university (The University of Chicago Press, Chicago, 2006), at pp. 141-143, $183-185,462-464$.

${ }^{11}$ Sylvia Paletschek, "Verbreitete sich ein "Humboldtsches Modell" an den deutschen Universitäten im 19. Jahrhundert?', in Humboldt international: der Export des deutschen Universitätsmodells im 19. und 20. Jahrhundert (ed. Rainer Christoph Schwinges), pp. 75-104 (Schwabe Verlag, Basel, 2001); Sylvia Paletschek, 'Eine deutsche Universität oder Provinz versus Metropole? Berlin, Tübingen und Freiburg vor 1914', in Die Berliner Universität im Kontext der deutschen Universitätslandschaft (ed. Rüdiger vom Bruch), pp. 213-242 (Oldenbourg, Munich, 2010). See also Dieter Langewiesche, 'Die "Humboldtsche Universität" als nationaler Mythos: zum Selbstbild der deutschen Universitäten im Kaiserreich und in der Weimarer Republik', Historische Zeitschrift, 290, 53-91 (2010); Johan Östling, Humboldt and the modern German university: an intellectual history (Lund: Lund University Press, 2018).

12 Vom Brocke, op. cit. (note 3), at p. 132. Friedrich Paulsen and Edward D. Perry, The German universities: their character and historical development (Macmillan and co., New York, 1895), at p. 236. The initiative of the imperial government to institutionalise official annual conferences for higher education officers from the federated governments in 1898 was not widely supported by the universities, who organised a first non-official all-German Rectors' Conference in 1903. Bernhard vom Brocke and Peter Krüger, 'Hochschulkonferenz - Rektorenkonferenz - Hochschullehrertag: Anfänge einer institutionalisierten Kooperation im deutschen Hochschulsystem', in Hochschulpolitik im Förderalismus: Die Protokolle der Hochschulrektorenkonferenzen der deutschen Bundesstaaten und Österreichs 1898 bis 1918 (eds Bernhard vom Brocke and Peter Krüger), p. 391 (Akademie Verlag, Berlin, 1994), at p. 391; see also note 124 below. 
${ }^{13}$ Voigt's title as the academic leader of the University of Göttingen was Prorektor. In many universities, like Göttingen, the Rektor (Rector) had historically been a representational figure such as the Head of State or another distinguished person. In other German universities, the title of Rektor already referred to the highest ranked academic officer, as it does in contemporary German universities. In this essay, we use the original German terms for all academic heads of universities and other professional roles and display those job role titles in italics.

${ }^{14}$ For the Anglophone readership, all French, German, and Latin titles of archival sources have been translated into English; page numbers are provided for archival documents with more than one page. For the quotes, see Woldemar Voigt, Prorektor of the University of Göttingen, to the Akademische Direktorium of the University of Heidelberg, Göttingen, 11 May 1912, typed in German, Heidelberg University Archives, RA 165, at p. 1, own translation. On Voigt's initiator role, see also Voigt to the Rektorat of the University of Heidelberg, Göttingen, 29 May 1912, typed in German, Heidelberg University Archives, RA 165; Report on the Royal Society jubilee by Voigt to August von Trott zu Solz, Minister der geistlichen Unterrichtsangelegenheiten (Minister of Intellectual and Educational Affairs) in Berlin, no place, 22 July 1912, handwritten in German, Göttingen University Archives, Sekr. 63-4.

${ }^{15}$ Notker Hammerstein, 'Epilogue: universities and war in the twentieth century', in $A$ history of the university in Europe: volume III: universities in the nineteenth and early twentieth centuries (1800-1945) (ed. Walter Rüegg), pp. 637-672 (Cambridge University Press, Cambridge, 2004), at pp. 637-639.

${ }^{16}$ Mitchell G. Ash, 'Wissenschaftswandlungen und politische Umbrüche im 20. Jahrhundert - was hatten sie miteinander zu tun?', in Kontinuitäten und Diskontinuitäten in der Wissenschaftsgeschichte des 20. Jahrhunderts (eds Rüdiger vom Bruch, Uta Gerhardt, and Aleksandra Pawliczek), pp. 19-38 (Franz Steiner Verlag, Stuttgart, 2006), at p. 25. 
${ }^{17}$ Sheila Jasanoff, 'Ordering knowledge, ordering society', in States of knowledge: the co-production of science and social order (ed. Sheila Jasanoff), pp. 13-45 (Routledge, New York, 2004), at pp. 22-36, 39-45; see also Steven Shapin and Simon Schaffer, Leviathan and the air-pump: Hobbes, Boyle, and the experimental life (Princeton University Press, Princeton, 1985); Bruno Latour, We have never been modern (Cambridge, MA, Harvard University Press, 1993); Bruno Latour, Pandora's hope: essays on the reality of science studies (Cambridge, MA, Harvard University Press, 1999); Anderson, op. cit. (note 3).

${ }^{18}$ Ash, op. cit. (note 16), at pp. 20-21, 25-27.

19 The triadic actor-network approach identifies materialities, dynamic hybrids (e.g., people, organisms, cyborgs, robots), and immaterialities as constitutive of actornetworks, assemblages, and resource ensembles. This conceptual trinity of actants aims to be more complex than the binary between humans and non-humans and is based on the understanding that materialities may signify meaning, immaterialities are physically embodied, and all entities can make a difference to the outcomes of practices, encounters, and events but only people and other dynamic hybrids are able to undertake practices. Heike Jöns, Grenzüberschreitende Mobilität und Kooperation in den Wissenschaften: Deutschlandaufenthalte US-amerikanischer HumboldtForschungspreisträger aus einer erweiterten Akteursnetzwerkperspektive (Heidelberg: Selbstverlag des Geographischen Instituts der Universität Heidelberg, 2003), at pp. 130168; Heike Jöns, 'Dynamic hybrids and the geographies of technoscience: discussing conceptual resources beyond the human/non-human binary, Social \& Cultural Geography, 7, 559-580 (2006), at pp. 573-574.

${ }^{20}$ Nina Glick Schiller, 'Cultural politics and the politics of culture', Identities: Global Studies in Culture and Power, 4, 1-7 (1997), at p. 2; Michael Heffernan, 'The changing political map: geography, geopolitics, and the idea of Europe since 1500', in An historical geography of Europe (eds R. A. Butlin and R. A. Dodgshon), pp. 140-180 (Oxford University Press, Oxford, 1998), at p. 148. 
${ }^{21}$ Martin Kintzinger, Wolfgang Eric Wagner, and Marian Füssel (eds), Akademische Festkulturen vom Mittelalter bis zur Gegenwart: zwischen Inaugurationsfeier und Fachschaftsparty (Schwabe Verlag, Basel, 2019); see especially Wolfgang Eric Wagner, 'Die Erfindung des Universitätsjubiläums im späten Mittelalter', in Akademische Festkulturen vom Mittelalter bis zur Gegenwart: Zwischen Inaugurationsfeier und Fachschaftsparty (eds Martin Kintzinger, Wolfgang Eric Wagner, and Marian Füssel), pp. 25-54 (Schwabe Verlag, Basel, 2019), at p. 29.

${ }^{22}$ Fox, op. cit. (note 1), at p. 19.

${ }^{23}$ Pieter Dhondt, 'Introduction: nineteenth-century university jubilees as the driving force of increasing Nordic cooperation', in National, Nordic or European? Nineteenthcentury university jubilees and Nordic cooperation (ed. Pieter Dhondt), pp. 1-9 (Brill, Leiden, 2011), at p. 2. See also Thomas P. Bekker, 'Jubiläen als Orte universitärer Selbstdarstellung: Entwicklungslinien des Universitätsjubiläums von der Reformationszeit bis zur Weimarer Republik', in Universität im öffentlichen Raum (ed. Rainer Christoph Schwinges), pp. 77-107 (Schwabe Verlag, Basel, 2008).

${ }^{24}$ Robert D. Anderson, 'University centenary ceremonies in Scotland 1884-1911', in National, Nordic or European? Nineteenth-century university jubilees and Nordic cooperation (ed. Pieter Dhondt), pp. 241-264 (Brill, Leiden, 2011), at pp. 259-262; Sylvia Paletschek, 'The writing of university history and university jubilees: German examples', Studium: Tijdschrift voor Wetenschaps- en Universiteitsgeschiedenis, 5, 142155 (2012), at pp. 150, 152; Pieter Dhondt, 'Introduction: university history writing: more than a history of jubilees', in University jubilees and university history writing: a challenging relationship (ed. Pieter Dhondt), pp. 1-17 (Brill, Leiden, 2015), at pp. 9-14. ${ }^{25}$ In March and November 1863, a Royal Ordinance and a new constitution were signed by the old and the new king of Denmark, respectively, aiming at the full incorporation of the duchy of Schleswig into the state of Denmark by 1 January 1864 . By separating Schleswig from Holstein, Denmark violated the Treaty of London of 1852, which had been signed at the end of the First Schleswig War (1848-1852) and confirmed 
Schleswig-Holstein's status as two linked duchies governed in personal union by the Danish king and his successors to the Danish throne. The violation against this provision meant that Denmark lost the support of its Nordic neighbours Norway and Sweden in the Second Schleswig War. Prussian and Austrian troops annexed the duchy of Holstein by marching into its territory on Christmas eve 1863, which prompted Danish toops to retreat voluntarily, but the subsequent occupation of Schleswig a month later, after Denmark refused to suspend the common constitution for Schleswig, resulted in the Second Schleswig War, which Michael Embree discusses as Otto von Bismarck's first of three wars that he led as Prussia's Minister-President and that paved the way for a united nation of Germany in 1871. Michael Embree, Bismarck's first war: the campaign of Jutland and Schleswig 1864 (Brill, Leiden, 2006), at pp. xv, 18-30.

${ }^{26}$ Dhondt, op. cit. (note 1), at pp. 7-9; Jorunn Sem Fure, 'The Royal Frederik University in Kristiania in 1911: intellectual beacon of the North - or "North Germanic" provincial university?', in University jubilees and university history writing: a challenging relationship (ed. Pieter Dhondt), pp. 57-82 (Brill, Leiden, 2015), at pp. 60-61. ${ }^{27}$ Anderson, op. cit. (note 24), at p. 241; Guðmundur Hálfdanarson, 'University of Iceland: a citizen of the Respublica Scientiarum or a nursery for the nation?', in National, Nordic or European? Nineteenth-century university jubilees and Nordic cooperation (ed. Pieter Dhondt), pp. 285-312 (Brill, Leiden, 2011), at p. 285.

${ }^{28}$ Paletschek, op. cit. (note 24), at p. 144.

${ }^{29}$ Ibid., at p. 145. With 100 overseas institutions represented through delegates at the Berlin centenary, especially from central and southern Europe and Russia but much fewer from the United Kingdom and the United States than at the Kristiania centenary, this international attention was lower than in Kristiania and comparable to St Andrews. Erich Schmidt, Jahrhundertfeier der Königlichen Friedrich-Wilhelm-Universität zu Berlin 10.-12. Oktober 1910: Bericht im Auftrag des Akademischen Senats erstattet von dem Prorektor Erich Schmidt (Universitäts-Buchdruckerei von Gustav Schade [Otto Francke], Berlin, 1911), at pp. 315-317; and Figure 1 below. 
30 Östling, op. cit. (note 11), at p. 52.

${ }^{31}$ Paletschek, op. cit. (note 24), at p. 150.

32 Norway's capital Christiania had been renamed Kristiania in 1877 and, after the original medieval settlement, Oslo in 1925. Synnøve Veinan Hellerud and Jan Messel, Oslo: a thousand-year history (Aschehoug, Oslo, 2000), at pp. 202, 243.

33 John Peter Collett, 'The Christiania University's 50 years celebration in 1861: national pride and Scandinavian solidarity', in National, Nordic or European? Nineteenth-century university jubilees and Nordic cooperation (ed. Pieter Dhondt), pp. 73-98 (Brill, Leiden, 2011), at pp. 73-77, 95.

${ }^{34}$ Ibid., at p. 94.

${ }^{35}$ Ibid., at p. 95 . Northern Schleswig was characterised by a majority of Danish speakers and has been a part of Denmark since the Schleswig plebiscite of 1920 . Southern Schleswig, which constitutes the northern part of the Federal Republic of Germany's most northern federal state of Schleswig-Holstein, had a considerable majority of German-speaking population but was under Danish rule c. 811-934 and c. 960-1864. Schleswig's southern boundary was the river Eider, which had also been the northern boundary of the Carolingian Empire. For Schleswig-Holstein's contested history 18481864, see Embree, op. cit. (note 25), at pp. 18-30.

${ }^{36}$ C. E. Tilley, 'Obituary: Waldemar Christofer Brögger 1851-1940', Biographical Memoirs of the Fellows of the Royal Society, 3, 503-517 (1941).

${ }^{37}$ Fure, op. cit. (note 26), at pp. 71-72.

${ }^{38}$ Bernhard vom Brocke, 'Die Kaiser-Wilhelm-Gesellschaft im Kaiserreich: Vorgeschichte, Gründung und Entwicklung bis zum Ausbruch des Ersten Weltkriegs, in Forschung im Spannungsfeld von Politik und Gesellschaft: Geschichte und Struktur der Kaiser-Wilhelm/Max-Planck-Gesellschaft: Aus Anlaß ihres 75jährigen Bestehens (eds Rudolf Vierhaus and Bernhard vom Brocke), pp. 17-162 (Deutsche Verlags-Anstalt, Stuttgart, 1990), at pp. 26-33. 
${ }^{39}$ Fure, op. cit. (note 26), at pp. 67-69. From the quincentenary celebrations in Leipzig (1909), Brøgger adopted the idea of a comprehensive university history as Festschrift, which was written by law scholar Bredo Morgenstierne. Robert Marc Friedman, 'Science, populist democracy and honour: the 1911 centenary celebration of the Royal Frederick University in Kristiania', in National, Nordic or European? Nineteenth-century university jubilees and Nordic cooperation (ed. Pieter Dhondt), pp. 267-284 (Brill, Leiden, 2011), at p. 275.

${ }^{40}$ Invitation by the rector and senate of the Royal Frederick University to the Royal Georg August University of Göttingen, Kristiania, December 1910, printed in Latin, Göttingen University Archives, Sekr. 68a.

${ }^{41}$ Preliminary Programme of the Centenary Celebrations of the Royal Frederick University, Kristiania, September 1911, printed in German, Göttingen University Archives, Sekr. 68a. The circulated draft programme saw only few changes but before the international guests arrived, the university organised a local ceremonial act and a church service on the preceding weekend. Fredrik Barbe Wallem (ed.), Det kongelige Frederiks Universitets hundreaarsjubilæum 1911 (A.W. Brøggers boktrykkeri a/s, Kristiania, 1913), at pp. 11-13.

42 Ibid., at pp. 15-21 for overseas institutions represented by delegates; at pp. 197-324 for printed addresses of Norwegian and overseas institutions; at pp. 325-326 for telegrams.

${ }^{43}$ G. H. Darwin, 'The centenary celebration of the University of Christiania', Nature, 87, 384-385 (1911), at p. 384. Darwin represented the institutions from the British Empire. The practice of choosing one speaker per country, empire, or region was already applied in Bologna 1888. Bericht des Geheimen Justizraths von Bar als Deputirten der Universität zur achthundertjährigen Jubelfeier der Universität Bologna (am 11., 12., 13. Juni 1888), Göttingen, 5 July 1888, handwritten in German, Göttingen University Archives, Sekr. 65, at p. 6.

${ }^{44}$ Fure, op. cit. (note 26 ), at pp. 71, 74. 
45 Thank-you address by the rector and academic senate of the Royal Frederick University, Kristiania, November 1911, printed in French, Göttingen University Archives, Sekr. 68a.

${ }^{46}$ Report on jubilees by Voigt to von Trott zu Solz, Göttingen, 18 September 1911, handwritten in German, Göttingen University Archives, Sekr. 68a, at p. 1.

${ }^{47}$ The quincentenary of the University of St Andrews (The University Press, Aberdeen, 1912), at pp. 6-38.

${ }^{48}$ Ibid., at p. 101 . From page 84 onwards, the proceedings of the St Andrews quincentenary reprinted press clippings from the Dundee Advertiser, some of which are quoted in this essay.

${ }^{49}$ Ibid., at p. 127; W. F. Gray, 'Bruce, Alexander Hugh, sixth Lord Balfour of Burleigh (1849-1921)', revised by H. C. G. Matthew, Oxford Dictionary of National Biography (2008), https://doi.org/10.1093/ref:odnb/32129 (accessed 4 December 2020); Brian Stanley, The World Missionary Conference: Edinburgh 1910 (William B. Eerdmans Publishing, Cambridge, 2009), at p. 250. The speech was also printed in The Times, where it reads 'The Empire would widen, and would require a new and deeper sense of individual responsibility'. 'The King and St. Andrews', The Times, Thursday, 14 September 1911.

${ }^{50}$ Geoffrey Wawro, Warfare and society in Europe, 1792-1914 (Routledge, London, 2000), at p. 185 .

${ }^{51}$ The quincentenary, op. cit. (note 47), at p. 130. The churches presented first, followed by the foreign universities. See also Ibid., at pp. 10-25.

${ }^{52}$ Ibid., at pp. 27-34. On the politics of honorary degree conferment, see Michael Heffernan and Heike Jöns, 'Degrees of influence: the politics of honorary degrees in the Universities of Oxford and Cambridge, 1900-2000', Minerva: A Review of Science, Learning and Policy, 45, 389-416 (2007).

${ }^{53}$ Arthur Köhler (ed.) Karl Lamprecht: Rektoratserinnerungen (Verlag Friedrich Andreas Perthes, Gotha, 1917), at pp. 26-27. 
${ }^{54}$ The quincentenary, op. cit. (note 47), with the two quotes at pp. 185-186, 187.

${ }^{55}$ Ibid., at p. 190.

${ }^{56}$ Ibid., at p. 189; Heffernan, op. cit. (note 5), at pp. 55-56.

${ }^{57}$ In response to the Latin invitations from the University of St Andrews, the universities of Göttingen and Heidelberg presented Latin addresses. Invitation by the rector and senate of the University of St Andrews to the Royal Georg August University of Göttingen, St Andrews, November 1910, printed in Latin; Congratulatory address from the prorector and senate of the Georg August University of Göttingen to the Chancellor, Vice-Chancellor, Deans, Heads of Colleges, and Professors of the University of St Andrews, Göttingen, August 1911, printed in Latin, Göttingen University Archives, Sekr. 68a; Congratulatory address from the prorector and senate of the Ruprecht Karls University of Heidelberg to the University of St Andrews, no place, no date, printed in Latin, Heidelberg University Archives, RA GF-59.

58 The quincentenary, op. cit. (note 47), at p. 193.

${ }^{59}$ Ibid., at pp. 196-197; Anderson, op. cit. (note 24), at p. 260. The warships are mentioned in W. C. M., 'Celebration of the five-hundredth anniversary of the foundation of the university of St. Andrews', Nature, 87, 385-388 (1911), at p. 388.

60 The quincentenary, op. cit. (note 47), at p. 196; Report on jubilees by Voigt to von Trott zu Solz, Göttingen, 18 September 1911, handwritten in German, Göttingen University Archives, Sekr. 68a, at p. 1.

${ }^{61}$ Report on jubilees by Voigt to von Trott zu Solz, Göttingen, 18 September 1911, handwritten in German, Göttingen University Archives, Sekr. 68a, with the quotes at pp. 1, 1-2, 2, own translation. On von Trott zu Solz, see Benigna von Krusenstjern, 'Trott zu Solz, August von', in Neue Deutsche Biographie, 26, pp. 457-458 (2017), https://www.deutsche-biographie.de/pnd117424447.html (accessed 4 December 2020). The jubilee proceedings list six honorary doctors from France; see The quincentenary, op. cit. (note 47), at pp. 27-34. 
62 Protokoll über die Verhandlungen des Parteitages der Sozialdemokratischen Partei Deutschland: abgehalten in Jena vom 10. bis 16. September 1911 sowie Bericht über die 6. Frauenkonferenz am 8. und 9. September 1911 in Jena (Buchhandlung Vorwärts, Berlin, 1911), at pp. 156-157, 333-350. See also note 50.

63 'Notes', Nature, 88, 15-19 (1911), at p. 15; 'Congress of the Universities of the Empire (1912)', Nature, 88, 56 (1911). See also Alex Hill, 'Preface', in The yearbook of the universities of the empire 1914: published for the Universities Bureau of the British Empire (ed. W. H. Dawson), pp. v-vi (Herbert Jenkins, London, 1914), at p. v, where 53 universities are mentioned, counting Trinity and Victoria colleges of the University of Toronto separately. Tamson Pietsch has commented that the 1912 Congress, at which Lord Rosebery delivered the opening address, followed upon the 1903 Allied Colonial Universities Conference as 'the first form of multilateral association of universities either in Britain or in the empire'. Tamson Pietsch, Empire of scholars: universities, networks and the British academic world, 1850-1939 (Manchester University Press, Manchester, 2013), at p. 95; see also pp. 1, 94-103.

${ }^{64}$ Invitation by Sir Archibald Geikie, President of the Royal Society, to the rector and members of the University of Göttingen's senate, Göttingen, 8 January 1912, printed in Latin, Göttingen University Archives, Sekr. 63-4.

${ }^{65}$ Extract from the senate's meeting minutes, Göttingen, 22 February 1912, typed in German, Göttingen University Archives, Sekr. 63-4.

${ }^{66}$ Prorektor and senate of the University of Göttingen to Geikie, Göttingen, 26 February 1912, typed in German, Göttingen University Archives, Sekr. 63-4; see also note 14. ${ }^{67}$ Voigt to the Akademische Direktorium of the University of Heidelberg, Göttingen, 11 May 1912, typed in German, Heidelberg University Archives, RA 165, at p. 1. 68 Johann Veit, Rektor of the University of Halle-Wittenberg, to the academic leaders of all non-Prussian German universities, Halle/Saale, 13 March 1912, typed in German, Göttingen University Archives, Sekr. 63-4, at p. 1. 
${ }^{69}$ Voigt to the academic leaders of all 21 German universities, Göttingen, 25 April 1912, handwritten in German, Göttingen University Archives, Sekr. 63-4, own translation. ${ }^{70}$ Ibid., own translation. See also Württembergische Metallwarenfabrik to Voigt, Geislingen-St., 14 February 1912 and 26 March 1912, typed in German, Göttingen University Archives, Sekr. 63-4.

${ }^{71}$ Voigt to the academic leaders of all 21 German universities, Göttingen, 25 April 1912, handwritten in German, Göttingen University Archives, Sekr. 63-4, at pp. 3-4, own translation. Ernst Beling, Rektor of the University of Tübingen, nevertheless suggested that the two dots after A. D. in the final line of the inscription should be removed because this would 'not correspond to the use in classical times'. In the final design, the two dots were centred vertically and horizontally (Figure 2). Beling to Voigt, Tübingen, 23 May 1912, typed in German, Göttingen University Archives, Sekr. 63-4, own translation.

72 Sigfried Sudhaus, Rektor of the University of Kiel, to Voigt, Kiel, 9 May 1912, typed in German, Göttingen University Archives, Sekr. 63-4, own translation.

${ }^{73}$ Karl von Lilienthal, Rektor of the University of Heidelberg, to Voigt, Heidelberg, 10 May 1912, typed in German, Heidelberg University Archives, RA 165, at p. 1, own translation. ${ }^{74}$ Adolf Kneser, Rektor of the University of Breslau, to Voigt, Breslau, 11 May 1912, typed in German; Fredrich Oltmanns, Prorektor of the University of Freiburg, to Voigt, Freiburg, 19 May 1912, typed in German, at pp. 1-2; Franz Erhardt, Rektor of the University of Rostock, to Voigt, Rostock, 21 May 1912, handwritten in German; Alois Knoepfler, Rektor of the University of Munich, to Voigt, Munich, 22 May 1912, typed in German, Göttingen University Archives, Sekr. 63-4.

${ }^{75}$ Veit, Rektor of the University of Halle-Wittenberg, to Voigt, Halle/Saale, 8 May 1912, typed in German; Georg Winter, Prorektor of the University of Königsberg, to Voigt, Königsberg, 8 May 1912, typed in German; Max Lenz, Rektor of the University of Berlin, to Voigt, Berlin, 17 May 1912, handwritten, Göttingen University Archives, Sekr. 63-4. 
${ }^{76}$ The agreement among all German universities was communicated to the academic leaders in writing at the end of May. Voigt to the Rektorat of the University of Heidelberg, Göttingen, 29 May 1912, typed in German, Heidelberg University Archives, RA 165.

77 Von Lilienthal to Voigt, Heidelberg, 10 May 1912, typed in German, at pp. 1-2; Voigt to the Rektorat of the University of Heidelberg, Göttingen, 29 May 1912, typed in German, Heidelberg University Archives, RA 165, at pp. 1-2; Karl Bernhard Lehmann, Rektor of the University of Würzburg, to Voigt, Würzburg, 18 May 1912, typed in German, at pp. 12; Franz Erhardt, Rektor of the University of Rostock, to Voigt, Rostock, 21 May 1912, handwritten in German; Georg Heinrici, Rektor of the University of Leipzig, to Voigt, Leipzig, 21 May 1912, typed in German, Göttingen University Archives, Sekr. 63-4. ${ }^{78}$ Von Lilienthal had written to all non-Prussian universities on 10 May 1912 to ask whether these universities would agree with regular coordination in the future. He enclosed his response to Voigt with the twofold proposal on how such a coordination could proceed. Von Lilienthal to the Rektoren of the non-Prussian universities, Heidelberg, 10 May 1912, handwritten in German; von Lilienthal to Voigt, Heidelberg, 10 May 1912, typed in German, at p. 2; the positive responses are also contained in Heidelberg University Archives, RA 165.

${ }^{79}$ Köhler, op. cit. (note 53), at pp. 13-14.

80 The presents are documented in Karl Binding, Die Feier des fünfhunderten Bestehens der Universität Leipzig: Amtlicher Bericht im Auftrage des Akademischen Senates (Verlag von S. Hirzel, Leipzig, 1910), at pp. 356-375, see also pp. 62f, 114f, 116f, $120 \mathrm{f}$. 81 The bronze relief was framed on the left by a young man with a torch, reminiscent of the young Greek god Apollo, and, on the right, by an old, bearded man holding an oil lamp and a scroll, potentially resembling Abraham, the founder of many nations and religions. Both men were standing on plinths bordering the congratulatory address above the depiction of a fight between a female lion standing upon a snake on a pedestal, and the years 1409-1909 engraved beneath this scene. The inscription read in capital letters: 
'For the University of Leipzig in memory of its 500 years of existence from the Technical College of Dresden'. Image of the bronze relief, Leipzig, 1909, engraved in German, Leipzig University Archives, Photo Collection, FS Ü00033, own translation. A digital copy is available at https://recherche.archiv.uni-leipzig.de/searchs/viewentry/B04845BDFD35-4A8B-8E8E-439B4721F890\# (accessed 4 December 2020).

82 The bronze plaques for Kristiania and St Andrews contained similar text apart from the spelling of 'Rektor' as 'Rector', 'Christiania' instead of 'St. Andrews', and 'einhundertjährigen Bestehens' instead of 'fünfhundertjährigen Bestehens'. The bronze plaque for St Andrews measured only $26.5 \mathrm{~cm} \times 15.0 \mathrm{~cm}$ in landscape format, was sparsely ornamented with volutes, rocaille, and floral elements on the sides and contained six lines in capital letters: 'Rector und Senat der Universität Leipzig - senden der Universität - St. Andrews - zur Feier ihres fünfhundertjährigen - Bestehens herzlichen Glückwunsch - Leipzig September 1911'. Congratulatory address received from Leipzig University, Leipzig, September 1911, flat metal plaque in display case, St Andrews University Archives, UYUY185/6, Box 2. For an image, see https://arts.standrews.ac.uk/digitalhumanities/fedora/repository/default\%3A513\#page/1/mode/2up (accessed 4 December 2020); Wallem, op. cit. (note 41), at p. 283. On Lamprecht's central role for the formation of German foreign cultural policy before WWI, see Rüdiger vom Bruch, 'Gesellschaftliche Initiativen in den auswärtigen Kulturbeziehungen Deutschlands vor 1914', Zeitschrift für Kulturaustausch, 31, pp. $43-67$ (1981); see also Jonas Flöter and Gerald Diesener (eds), Karl Lamprecht (1856-1915): Durchbruch in der Geschichtswissenschaft (Leipziger Universitätsverlag, Leipzig, 2015).

${ }^{83}$ Voigt to the Rektoren of all German universities, Göttingen, 25 April 1912, handwritten in German, Göttingen University Archives, Sekr. 63-4, at p. 2.

${ }^{84}$ Bosselt was a leading German sculptor and medallist. For his biography and oeuvre, see Vera Losse, Rudolf Bosselt: Erneuerer der deutschen Medaillenkunst: Bildhauer und Reformpädagoge: mit Werkverzeichnis der plastischen Arbeiten (Letter Stiftung, Köln, 1995). 
${ }^{85}$ Archibald Geikie, A long life's work: an autobiography (Cambridge University Press, Cambridge, 1924), at p. 382 and own translation. Congratulatory addresses were often presented in Latin and printed on richly ornamented oversized paper. See, for example, congratulatory addresses, Heidelberg University Archives, GF-59.

${ }^{86}$ Sandra Gambetti, The Alexandrian riots of 38 C.E. and the persecution of the Jews: a historical reconstruction (Brill, Leiden, 2009), at pp. 130, 129-135.

${ }^{87}$ Voigt to the Rektorat of the University of Heidelberg, Göttingen, 8 July 1912, typed in German, Heidelberg University Archives, RA 165, own translation.

${ }^{88}$ Hoerdes, op. cit. (note 7), at pp. 98-100.

${ }^{89}$ For the politics of geographical imaginations and their role in changing both individual identities and collective understandings of power, knowledge, and geography, see Derek Gregory, Geographical imaginations (Blackwell, Oxford, 1994); Susan Schulten, The geographical imagination in America, 1880-1950 (The University of Chicago Press, Chicago, 2001); Michael Heffernan, The European geographical imagination (Franz Steiner, Stuttgart, 2006).

90 Von Lilienthal to Voigt, Heidelberg, 18 May 1912, typed in German, Heidelberg University Archives, RA 165.

${ }^{91}$ Voigt to von Lilienthal, Göttingen, 20 May 1912, handwritten in German, Heidelberg University Archives, RA 165, at pp. 1-2.

92 Von Lilienthal to Voigt, Heidelberg, 22 May 1912, typed in German, Heidelberg University Archives, RA 165, own translation. The costs of the tablet were divided between the 21 German universities based on their share of students in the summer semester 1911 and the winter semester 1911/12. The original cost estimate of 1,200 Mark was raised to $1,319.45$ Mark, with the largest shares being paid by the three biggest universities of Berlin (14\%), Munich (12\%), and Leipzig (9\%). For details, see Voigt's invoice on the tabula gratulatoria for the Royal Society in London in July 1912, typed in German, Göttingen, 19 August 1912, Göttingen University Archives, Sekr. 63-4. 
${ }^{93}$ For details, see Geikie, op. cit. (note 85 ). See also John Betterton, Jonathan Craig, John R. Mendum, Robert Neller, and Julia Tanner (eds) Aspects of the life and works of Archibald Geikie (London, The Geological Society, 2019).

${ }^{94}$ Ibid., at p. 262, see also p. 141.

${ }^{95}$ Voigt to Geikie, Göttingen, 5 July 1912, typed in German, Göttingen University Archives, Sekr. 63-4.

${ }^{96}$ Geikie, op. cit. (note 85), at p. 210.

${ }^{97}$ Robert William Frederick Harrison, Assistant Secretary to the Royal Society, to Voigt, 10 July 1912, typed in English, Royal Society Archives, London, NLB/46/195.

${ }^{98}$ Geikie, op. cit. (note 85), at p. 379.

${ }^{99}$ For overseas universities and academies represented through delegates at the Berlin centenary, see Schmidt, op. cit. (note 29), at pp. 315-317; and note 29 above.

${ }^{100}$ Archibald Geikie, 'Address of the president, Sir Archibald Geikie, K. C. B., at the anniversary meeting on November $30,1912^{\prime}$, Proc. R. Soc. Lond. A, 88, 1-12 (1913), at p. 7.

${ }^{101}$ Report on the Royal Society jubilee by Voigt to von Trott zu Solz, no place, 22 July 1912, handwritten in German, Göttingen University Archives, Sekr. 63-4, at p. 2, own translation. For the event programme, see The Royal Society: $250^{\text {th }}$ anniversary: diary, programme of proceedings and list of delegates, Burlington House, London, 15-18 July 1912, printed in English, Royal Society Archives, London, MS_552_250, at pp. 3-9. For the awards of honorary degrees, see Royal Society (ed.), The celebration of the two hundred and fiftieth anniversary of the Royal Society of London, 15-19 July 1912 (Royal Society, London, 1913), at pp. 24-30.

102 Report on the Royal Society jubilee by Voigt to von Trott zu Solz, no place, 22 July 1912, handwritten in German, Göttingen University Archives, Sekr. 63-4, at pp. 1-2. In a third letter to all non-Prussian German universities (with the exception of Munich) dated 20 June 1912, Veit had asked the Rektoren and Prorektoren of these institutions whether their delegates would support the proposal of all Prussian universities and the University 
of Munich that the joint speech and present would be delivered by the delegate of the University of Göttingen. This proposal was unanimously accepted but not without the request from Heidelberg that the non-Prussian universities should be consulted before such proposals are made. Veit to von Lilienthal, Halle/Saale, 20 June 1912, typed in German; von Lilienthal to Veit, Heidelberg, 29 June 1912, handwritten in German, Heidelberg University Archives, RA 165.

103 'The Royal Society: Celebration of the $250^{\text {th }}$ anniversary: Presentation of addresses', The Times, Wednesday, 17 July 1912. The bronze tablet's dimensions and weight are mentioned in the letter by the Württembergische Metallwarenfabrik to Voigt, GeislingenSt., 26 March 1912, typed in German, Göttingen University Archives, Sekr. 63-4, at pp. 1-2; see also Voigt to von Lilienthal, Göttingen, 20 May 1912, handwritten in German, Heidelberg University Archives, RA 165, at p. 1. On the passenger luggage, see Voigt to Rudolf Bosselt, Göttingen, 1 July 1912, typed in German, Göttingen University Archives, Sekr. 63-4.

${ }^{104}$ Speech given by Voigt at the reception of delegates in the Great Library of the Royal Society, London, 16 July 1912, typed in English with handwritten corrections, Göttingen University Archives, Sekr. 63-4, at p. 1.

105 Ibid.

${ }^{106}$ Ibid. The unveiling of the bronze tablet is mentioned in 'The Royal Society: celebration of the $250^{\text {th }}$ anniversary: presentation of addresses', The Times, Wednesday, 17 July 1912.

107 Speech given by Voigt at the reception of delegates in the Great Library of the Royal Society, London, 16 July 1912, typed in English with handwritten corrections, Göttingen University Archives, Sekr. 63-4, at pp. 1-2.

${ }^{108}$ Ibid., at p. 2.

${ }^{109}$ Report on Royal Society jubilee by Voigt to von Trott zu Solz, no place, 22 July 1912, handwritten in German, Göttingen University Archives, Sekr. 63-4, at p. 2, own translation. 
${ }^{110}$ Ludwig Stein was a Hungarian-born Swiss citizen and Professor of Philosophy and Sociology at the University of Berne before serving as the editor of Nord und Süd in Berlin in the years $1912-1920$ and $1927-1930$. His academic biography is discussed by Jacob Haberman, 'Ludwig Stein: Rabbi, Professor, Publicist, and Philosopher of Evolutionary Optimism', The Jewish Quarterly Review, 86, 91-125 (1995).

${ }^{111}$ Vom Bruch, op. cit. (note 82), at p. 52; A. J. Balfour, 'Offener Brief an den Herausgeber', Nord und Süd, 36, 284-289 (1912). Arthur Balfour was also long-term Chancellor of the University of Edinburgh but did not attend the jubilees in Kristiania, St Andrews, and the Royal Society.

112 Geikie to Horace Hart, Printer to the University of Oxford and Controller of the University Press, 29 May 1913, handwritten in English, Royal Society Library and Archives, NLB/48/191.

${ }^{113}$ Royal Society, op. cit. (note 101), at p. 48; see also Figure 2 above.

${ }^{114}$ The geologist's affinity for Latin had begun at school with his translation of 'Ovid's account of the Four Ages into English heroic metre', published at the age of 14 as part of Dr Steven's book on the History of the High School of Edinburgh. An ongoing interest in Latin was exemplified by The Love of Nature among the Romans during the Later Decades of the Republic and the First Century of the Empire (John Murray, London, 1912), a book based on Geikie's address to the Classics Association in January 1911 and reviewed in the journal Nature in October 1912. Geikie, op. cit. (note 85), at pp. 12-13; T. Herbert Warren, 'The love of nature among the Romans during the later decades of the republic and the first century of the Empire', Nature, 90, 185-187 (1912). ${ }^{115}$ Matthias Winner, 'The orb as the symbol of the state in the pictorial cycle by Rubens depicting the life of Maria de' Medici', in Iconography, propaganda, and legitimation (ed. Allan Ellenius), pp. 63-86 (Clarendon Press, Oxford, 1998), at p. 86.

${ }^{116}$ Archibald Geikie, 'Address of the President, Sir Archibald Geikie, K. C. B., at the Anniversary Meeting on November 30, 1912', Proc. R. Soc. Lond. A, 88, 1-12 (1913), at 
pp. 8-9; The Royal Society (ed.), Copley medal https://royalsociety.org/grants-schemesawards/awards/copley-medal/ (accessed 4 December 2020).

117 Voigt to unspecified addressee, Göttingen, 29 June 1913, handwritten in German, Göttingen University Archives, Kuratorium 5943, Personal file for Voigt, BI. 167; Archibald Geikie, 'Address of the President, Sir Archibald Geikie, K. C. B., at the Anniversary Meeting on December 1, 1913', Proc. R. Soc. Lond. A, 89, 451-468 (1913). 118 This boycott of German science and language was lifted in June 1926. Bernhard vom Brocke, 'Wissenschaft und Militarismus', in Wilamowitz nach 50 Jahren (eds William M. Calder III, Hellmut Flashar, and Theodor Lindken), pp. 649-719 (Wissenschaftliche Buchgesellschaft, Darmstadt, 1985), at p. 681; Roswitha Reinbothe, Deutsch als internationale Wissenschaftssprache und der Boykott nach dem Ersten Weltkrieg. 2., überarbeitete und erweiterte Auflage (De Gruyter, Berlin, 2019), at pp. 2, 464.

119 Geikie, op. cit. (note 85), at p. 382.

${ }^{120}$ Ibid., at pp. 385-386.

${ }^{121}$ For the role of social networks in academic careers and the development of British and imperial universities, see Tamson Pietsch, Empire of scholars: universities, networks and the British academic world, 1850-1939 (Manchester University Press, Manchester, 2013), especially chapter 5. For the impact of academic travel and social networks on changing global geographies of knowledge production, imperial reform, and an emerging Anglo-American hegemony, see Heike Jöns, 'The University of Cambridge, academic expertise and the British Empire, 1885-1962', in Mobilities of knowledge (eds Heike Jöns, Peter Meusburger, and Michael Heffernan), pp. 185-210 (Springer, Cham, 2017). 122 Trude Maurer, 'Commitment, reserve and self-assertion: the celebration of patriotic anniversaries in Russian and German universities 1912/13', in University jubilees and university history writing: a challenging relationship (ed. Pieter Dhondt), pp. 83-93 (Brill, Leiden, 2015), at p. 86.

${ }^{123}$ Ibid. 
${ }^{124}$ Bernhard vom Brocke and Peter Krüger, 'Vorwort', in Hochschulpolitik im Förderalismus: Die Protokolle der Hochschulrektorenkonferenzen der deutschen Bundesstaaten und Österreichs 1898 bis 1918 (eds Bernhard vom Brocke and Peter Krüger), pp. xiii-xiv (Akademie Verlag, Berlin, 1994), at p. xiii; vom Brocke and Krüger, op. cit. (note 12), at p. 391.

${ }^{125}$ Ibid.; Minutes of the proceedings of the fourth non-official German Rectors' Conference, Halle/Saale, 12 March 1914, typed in German, Heidelberg University Archives, RA 164, p. 1, first parenthesis.

${ }^{126}$ Minutes of the proceedings of the fourth non-official German Rectors' Conference, Halle/Saale, 12 March 1914, typed in German, Heidelberg University Archives, RA 164, p. 3, point 10. The annual non-official Prussian Conference of Rectors, 1904-1914 and 1918-1919, and the annual non-official all-German Rectors' Conferences, 1913-1914, 1916, and 1918, were held in Halle, with missing years because of the war. Vom Brocke and Krüger, op. cit. (note 12), at p. 391.

127 See note 78 and Stiftung zur Förderung der Hochschulrektorenkonferenz (ed.) HRK Hochschulrektorenkonferenz: Die Stimme der Hochschulen https://www.hrk.de/hrk/geschichte/ (accessed 4 December 2020). ${ }^{128}$ Minutes of the proceedings of the fourth non-official German Rectors' Conference, Halle/Saale, 12 March 1914, typed in German, Heidelberg University Archives, RA 164, p. 2 (point 7) and p. 1 (point 3).

${ }^{129}$ Academische Senaat (ed.), Academia groningana, 29 Juni-1 Juli 1914: verslag van de herdenking van het derde eeuwfeest der Universiteit te Groningen (J. B. Wolters, Groningen, 1916).

130 The event proceedings record an address from Pisa but name no delegate who handed this over in the morning of 30 June. Vincenzo Ussani, a classicist from Palermo, who had received a poetry price in Amsterdam a few years earlier, is listed to have attended the evening dinner on 30 June but no address was presented from Palermo. Ibid., at pp. 25, 87, 115. On the local election date, see Maurizio Degl'Innocenti, Identità 
nazionale e poteri locali in Italia tra '800 e '900 (P. Lacaita, Manduria, 2005), at p. 307; on the previous event absence of an Italian, see Klaas van Berkel, Universiteit van het Noorden: vier eeuwen academisch level in Groningen: deel II: de klassieke universiteit, 1876-1945 (Uitgeverij Verloren, Hilversum, 2017), at p. 766.

${ }^{131}$ Academische Senaat, op. cit. (note 129), at pp. 1-4. The invitation to the University of Heidelberg contained a note in German that a response about the nominated delegate would be requested by 14 February 1914. Rector and senate of the University of Groningen to the University of Heidelberg, Groningen, 4 December 1913, printed in Latin with typed note in German, Heidelberg University Archives, RA 164.

${ }^{132}$ For the varying numbers of British institutions represented in Groningen (20 universities and 4 learned societies versus 20 universities and 2 learned societies from the German Empire) and printed addresses, see Academische Senaat, op. cit. (note 129), at pp. 23-24, 74-85. On the Universities Bureau of the British Empire, whose foundation was agreed on the last day of the 1912 Congress of the Universities of the Empire, see Eric Ashby, Communities of universities: an informal portrait of the Association of Universities of the British Commonwealth 1913-1963 (University Press, Cambridge, 1963); Pietsch, op. cit. (note 121), especially pp. 101-103. For the yearbooks, see Richard Kukula and Karl Trübner (eds), Minerva: Jahrbuch der Universitäten der Welt: Erster Jahrgang: 1891-1892 (Karl J. Trübner, Strassburg, 1891); Hill, op. cit. (note 63).

${ }^{133}$ Academische Senaat, op. cit. (note 129), at p. 22.

${ }^{134}$ Alois Schulte, Rektor of the University of Bonn, to the Rektor of the University of Heidelberg (the economic historian Eberhard Gothein), Bonn, 11 July 1914, typed in German, Heidelberg University Archives, RA 164, at p. 2.

135 The Royal Society's tablet does not seem to have been officially recorded after the publication of the anniversary proceedings in 1913, and it is also not documented as part of Bosselt's work. See, for example, Henry Lyons (ed.) The record of the Royal Society of London. $4^{\text {th }}$ edition (Royal Society, London, 1940); Vera Losse, Rudolf Bosselt: Bildhauer 
und Medailleur 1871-1938 (Institut Mathildenhöhe, Darmstadt, 1994); Losse, op. cit. (note 84).

${ }^{136}$ Klaas van Berkel, Universiteit van het Noorden: vier eeuwen academisch level in Groningen: deel II: de klassieke universiteit, 1876-1945 (Uitgeverij Verloren, Hilversum, 2017), at p. 424. Personal e-mail communication by Dr Arjen Dijkstra, Head of the University Museum Groningen, University of Groningen, 2020. The Groningen bronze tablet measures $95 \mathrm{~cm} \times 69.5 \mathrm{~cm}$ and thus almost equals the size of the Royal Society's. 137 During WWII, Britain used the award of honorary degrees successfully as a strategy of foreign cultural policy, when the University of Oxford awarded such degrees in 1941 to the Portuguese Prime Minister António de Oliveira Salazar and US President Franklin Delano Roosevelt in order to convince the leaders of these neutral countries either-in the case of Portugal-to stay out of the war or-in the case of the United States-to enter the war in support of Britain and her allies; see Heffernan and Jöns, op. cit. (note 52), at p. 397.

138 Losse, op. cit. (note 135), at p. 51.

139 M. Yakup Bektas and Maurice Crosland, 'The Copley medal: the establishment of a reward system in the Royal Society, 1731-1839', Notes and Records of the Royal Society, 46, 43-76 (1992), at pp. 43, 47.

${ }^{140}$ For a detailed discussion of the Copley medal's iconography, see Rebekah Higgitt, '"In the Society's strong box": a visual and material history of the Royal Society's Copley medal, c. 1736-1760', Nuncius, 34, 284-316 (2019), at pp. 296-307, especially pp. 297-298.

${ }^{141}$ Losse, op. cit. (note 135), at p. 51.

${ }^{142}$ Ibid., at p. 50, lines 1, 3, 4, 7-9. The size of the Frankfurt bronze plaque is $8.1 \mathrm{~cm} \mathrm{x}$ $14.8 \mathrm{~cm}$ (Figure 4). For the backside, see Münzkabinett, Staatliche Museen zu Berlin, 18234647; https://ikmk.smb.museum/object?id=18234647 (accessed 4 December 2020).

143 'Britain's destiny and duty', The Times, Friday, 18 September 1914. 
144 Vom Brocke, op. cit. (note 118), at pp. 654-665, 718.

145 Reinbothe, op. cit. (note 118 ), at p. 572, own translation.

${ }^{146}$ Ibid., own translation. The few professors who did not sign the declaration included the military historian Hans Delbrück and the physical chemist and initiator of the Solvay Conferences Walther Nernst (both Berlin) as well as the geologist Wilhelm Salomon-Calvi and the brothers Max and Alfred Weber (all Heidelberg). Erklärung der Hochschullehrer des Deutschen Reiches [Berlin, den 16. Oktober 1914] (Berlin: Kaiser-Wilhelm-Dank, 1914) https://nbn-resolving.org/urn:nbn:de:bvb:210-16-007530116-3 (accessed 4 December 2020). Hans Delbrück and Max Weber were members of the German delegation at the peace negotiations in Versailles and signed with two others the Professorengutachten, 'a memo by internationally respected "learned men" defending Germany against the charge of sole war guilt'. Jan Stöckmann, 'Studying the international, serving the nation: the origins of international relations (IR) scholarship in Germany, 1912-33', The International History Review, 38, 1055-1080, at p. 1058. 147 This reconstruction of the chronology is based on newspaper archives as well as Jürgen von Ungern-Sternberg and Wolfgang von Ungern-Sternberg, Der Aufruf 'An die Kulturwelt!': das Manifest der 93 und die Anfänge der Kriegspropaganda im Ersten Weltkrieg: mit einer Dokumentation (Franz Steiner Verlag, Stuttgart, 1996), at pp. 2526; Hammerstein, op. cit. (note 15), at pp. 641-642; Hoerdes, op. cit. (note 7), at p. 126-128; Reinbothe, op. cit. (note 118), at pp. 567-572. For more reactions, see vom Brocke, op. cit. (note 118).

148 William Crookes, 'Address of the President, Sir William Crookes, O. M., at the Anniversary Meeting on November 30, 1914', Proc. R. Soc. Lond. A, 91, 106-119 (1914), at p. 114. ${ }^{149}$ Ibid., at p. 115.

${ }^{150}$ Ibid., at p. 114; Otto Glasser, Wilhelm Conrad Röntgen and the early history of the Roentgen rays (Norman Publishing, San Francisco, 1993), at p. 168. Röntgen had reacted to a call for gold in support of the war but kept his 1901 Nobel Prize medal. Vom 
Brocke, op. cit. (note 118), at p. 715; see also Gerd Rosenbusch and Annemarie de Knecht-van Eekelen, Wilhelm Conrad Röntgen: the birth of radiology (Springer, Cham, 2019), at p. 142.

${ }^{151}$ See especially Ash, op. cit. (note 16); Dhondt, op. cit. (note 1); Hammerstein, op. cit. (note 15); Jasanoff, op. cit. (note 17); McClelland, op. cit. (note 4); Paletschek, op. cit. (note 24); Smith, op. cit. (note 4); vom Brocke, op. cit. (note 118); and Rüdiger vom Bruch, Uta Gerhardt, and Aleksandra Pawliczek (eds), Kontinuitäten und Diskontinuitäten in der Wissenschaftsgeschichte des 20. Jahrhunderts (Franz Steiner Verlag, Stuttgart, 2006).

152 Ash, op. cit. (note 16), at pp. 19-20, 33-37. For the identification of 1914 as the start of a new phase in the history of international science through the onset of an age of global wars (WWI, WWII, Cold War) and the use of science-intensive weaponry, see Crawford, Shinn, and Sörlin, op. cit. (note 1), at pp. 6, 21. For continuities and discontinuities in the organisation of German and Austrian Ministries of Culture, see Bernhard vom Brocke, 'Kultusministerien und Wissenschaftsverwaltungen in Deutschland und Österreich: Systembrüche und Kontinuitäten 1918/19 - 1933/38 - 1945/46', in Wissenschaften und Wissenschaftspolitik: Bestandsaufnahmen zu Formationen, Brüchen und Kontinuitäten im Deutschland des 20. Jahrhunderts (eds Rüdiger vom Bruch and Brigitte Kaderas), pp. 193-214 (Franz Steiner Verlag, Stuttgart, 2002).

${ }^{153}$ For the institutionalisation and consequences of this comprehensive scientific boycott of Germany and its allies after WWI, see Reinbothe, op. cit. (note 118). 